\title{
Timing of sea-ice retreat affects the distribution of seabirds and their prey in the southeastern Bering Sea
}

\author{
George L. Hunt Jr. ${ }^{1, *}$, Martin Renner ${ }^{2}$, Kathy J. Kuletz ${ }^{3}$, Sigrid Salo ${ }^{4}$, Lisa Eisner ${ }^{5}$, \\ Patrick H. Ressler ${ }^{5}$, Carol Ladd ${ }^{4}$, Jarrod A. Santora ${ }^{6}$ \\ ${ }^{1}$ School of Aquatic and Fishery Sciences, University of Washington, Box 355020, Seattle, WA 98195, USA \\ ${ }^{2}$ Tern Again Consulting, 811 Ocean Drive Loop, Homer, AK 99603, USA \\ ${ }^{3}$ US Fish and Wildlife Service, Migratory Bird Management, 1011 E. Tudor Rd., Anchorage, AK 99503, USA \\ ${ }^{4}$ NOAA-Pacific Marine Environmental Laboratory, 7600 Sand Point Way NE, Seattle, WA 98115, USA \\ ${ }^{5}$ NOAA-Alaska Fisheries Science Center, 7600 Sand Point Way NE, Seattle, WA 98115, USA \\ ${ }^{6}$ Department of Applied Math and Statistics, Center for Stock Assessment Research, University of California Santa Cruz, \\ 110 Shaffer Road, Santa Cruz, CA 95060, USA
}

\begin{abstract}
The potential impacts of future climate warming on marine ecosystems can be assessed by examining the effects of present-day variation in climate. Here we report how the cross-shelf distributions of seabirds and their potential prey responded to interannual variation in the timing of sea-ice retreat in the southeastern Bering Sea. We expected that in years of early sea-ice retreat, prey resources would be scarce over the shelf and that seabird species would concentrate in frontal regions where availability of zooplankton and forage fish might be enhanced. To test this hypothesis, we used a $40 \mathrm{yr}$ database of the distribution of marine birds and recently available data on the distribution of zooplankton and forage fish. We found that although there were substantial changes in the distribution of seabird species between years with early and late sea-ice retreat, there was no overall shift into frontal regions. Instead, in years with early sea-ice retreat, there was a strong tendency for seabird species that foraged off the shelf to move toward, or onto, the shelf, whereas inshore-foraging species shifted seaward. Further, the cross-shelf centers of abundance of the copepod Calanus marshallae/ glacialis shifted seaward, but there was little change in the cross-shelf distributions of Neocalanus spp. copepods, euphausiids (primarily Thysanoessa spp.), and age-0 pollock Gadus chalcogrammus. Shifts in seabird distributions, as demonstrated in this study, indicate the importance of sea-ice retreat for structuring trophic interactions and could present both opportunities and challenges for centralplace-foraging breeding seabirds and long-distance migratory species.
\end{abstract}

KEY WORDS: Climate variability · Southeastern Bering Sea $\cdot$ Calanus glacialis $\cdot$ Calanus marshallae Gadus chalcogrammus $\cdot$ Neocalanus spp. Thysanoessa raschii

'Seabirds are like graduate students; they go where the food is.'

Comment by Bob Paine on the occasion of an after-dinner talk on Seabirds as Feathered Oceanographers

\section{INTRODUCTION}

Marine ecosystems respond to climate forcing at a variety of temporal scales, from those of storm events,

${ }^{*}$ Corresponding author: glhunt@uci.edu

${ }^{\S}$ Advance View was available online March 1, 2018 to periods of cooling and warming lasting millennia. While seasonal variability in heat and light is manifested in the ocean by changes in production and by migration of organisms to more favorable locations, changes in climate forcing lasting multiple years and longer may result in major reorganizations of food webs and ecosystem structure (e.g. Drinkwater 2006, Beaugrand \& Kirby 2010, Sydeman et al. 2015). In the

(C) The authors 2018. Open Access under Creative Commons by Attribution Licence. Use, distribution and reproduction are unrestricted. Authors and original publication must be credited. 
southeastern Bering Sea, unusually warm or cold years have resulted in shifts in ecosystem components, including the relative abundance of phytoplankton cells of different sizes (Eisner et al. 2016), zooplankton (Coyle et al. 2011), the abundance of euphausiids (Hunt et al. 2016), the diets and lipid content of age- 0 and age- 1 pollock (Coyle et al. 2011, Heintz et al. 2013), the survival of these young pollock to age-3 (Hunt et al. 2011, Eisner \& Yasumiishi 2016), and changes in the distributions of fish species (Mueter \& Litzow 2008). Some studies indicate that climate change may have a greater impact through affecting biotic linkages than through the direct impacts of warming (e.g. Drinkwater et al. 2010, Søreide et al. 2010, Ockendon et al. 2014).

An indication of the potential impacts of future climate warming on marine ecosystems can be obtained by investigating the effects of present shortterm (years to decades) variations in climate. In this paper, we compare and contrast the cross-shelf distributions of southeastern Bering Sea seabirds and their prey in years with early and late sea-ice retreat to see how this ecosystem may respond to climate warming.

The eastern Bering Sea is noted for the interannual variability of its marine conditions (Stabeno et al. 2001, 2012, Hermann et al. 2013). Located at the southern terminus of the winter arctic sea-ice extent in the Pacific Arctic, the southeastern Bering Sea experiences strong interannual variability in spring sea-ice cover. This is manifested in variability in seaice extent, percent cover, and the timing of sea-ice retreat (Niebauer 1998, Stabeno et al. 2001). The timing of sea-ice retreat affects the availability of iceassociated algae and possibly the timing, intensity, and duration of the spring bloom (Alexander \& Niebauer 1981, Stabeno et al. 1998, Hunt et al. 2002b, 2011, Brown \& Arrigo 2013).

Variations in the timing of sea-ice retreat affect food availability for zooplankton in spring (Smith \& Vidal 1986, Niebauer et al. 1990, Napp et al. 2002) and thereby the potential for transfer of energy to fish, seabirds, and marine mammals. Recent work has shown that the distribution and abundance of large crustacean zooplankton and forage fish respond to variability in the timing of sea-ice retreat and/or water temperatures (Baier \& Napp 2003, Coyle et al. 2011, Hunt et al. 2011, 2016, Eisner et al. 2014, Coyle \& Gibson 2017). In particular, there is considerable information on changes in the abundance of large copepods (Coyle et al. 2011, Eisner et al. 2014, 2015), euphausiids (principally Thysanoessa spp.) (Ressler et al. 2012, 2014, Hunt et al. 2016), juvenile walleye pollock Gadus chalcogrammus (hereafter 'pollock'), and Pacific cod G. macrocephalus (Hunt et al. 2002b, 2008, Farley et al. 2016, Sigler et al. 2016), as well as the survival of the pollock to age1 or age-3 (Mueter et al. 2011, Heintz et al. 2013, Sigler et al. 2016), in relation to the timing of sea-ice retreat. In warm years, when sea-ice retreat occurs early in the spring, there are reduced abundances of the large, lipid-rich copepods and middle shelf euphausiids and usually weaker year classes of pollock and Pacific cod.

Associations between seabirds and their prey occur at spatial scales, from those of ocean basins, to Langmuir circulation cells and individual prey (reviewed in Hunt \& Schneider 1987, Hunt et al. 1999). Seabirds respond to changes in the distribution or abundance of their prey by shifting their foraging distributions (e.g. Takahashi et al. 2015, Nishizawa et al. 2017; Will \& Kitaysky 2018, Will et al. 2018, both this Theme Section), although relatively few studies have simultaneous measures of seabird foraging activity and the abundance of prey (e.g. Hunt \& Harrison 1990, Kokubun et al. 2008, Suryan et al. 2016). The distribution and abundance of seabirds over the southeastern Bering Sea shelf has been a topic of research since the mid-1970s. Initially, the emphasis was on large-scale static distributions (e.g. Hunt et al. 1981, Schneider et al. 1986, 1987), as time series were not available, or on small-scale process studies where interactions between the behavior of prey and physical processes result in concentrations of prey (e.g. Coyle et al. 1992, Hunt et al. 1996, Jahncke et al. 2005). In particular, seabirds respond to prey accumulations in frontal regions, either because of convergences or divergences (e.g. Coyle et al. 1992, Hunt et al. 1998), or because of enhanced or prolonged primary production (e.g. Jahncke et al. 2005).

Recently, as a substantial time series of pelagic observation of seabirds has become available, there has been more emphasis on changes in distribution or abundance at decadal time scales or longer, both in the eastern Bering Sea (e.g. Jahncke et al. 2008, Kuletz et al. 2014, Renner et al. 2016) and in the adjacent Chukchi Sea (Gall et al. 2017). The finding of strong seasonal signals in both abundance (Schneider et al. 1986) and distribution (Hunt et al. 2014) has raised interest in the possibility that seabird distributions across the southeastern Bering Sea shelf might vary at a multi-annual time scale in response to variation in the abundance or availability of prey.

In this paper, we examine interannual patterns of seabird distribution across the southeastern Bering Sea shelf, and relate these patterns to spatial and 
temporal variability in the marine environment, including timing of seaice retreat and the distribution and abundance of potential prey such as large crustacean zooplankton and forage fish. We use a 40 yr data set of pelagic seabird observations from the eastern Bering Sea to assess changes in the cross-shelf distribution of seabirds and potential prey organisms to test the hypothesis that shifts in seabird distribution reflect temporal variability in the distribution of their prey, which in turn, may have been affected by the timing of sea-ice retreat.

We hypothesized that seabirds would shift their centers of distribution toward frontal areas when conditions were such that large lipid-rich copepods and euphausiids and forage fish were scarce in the inner and middle portions of the shelf. Because large, lipid-rich crustacean zooplankton were expected to be less abundant in years with early sea-ice retreat, and thus, perhaps, the only concentrations might be available near fronts with strong

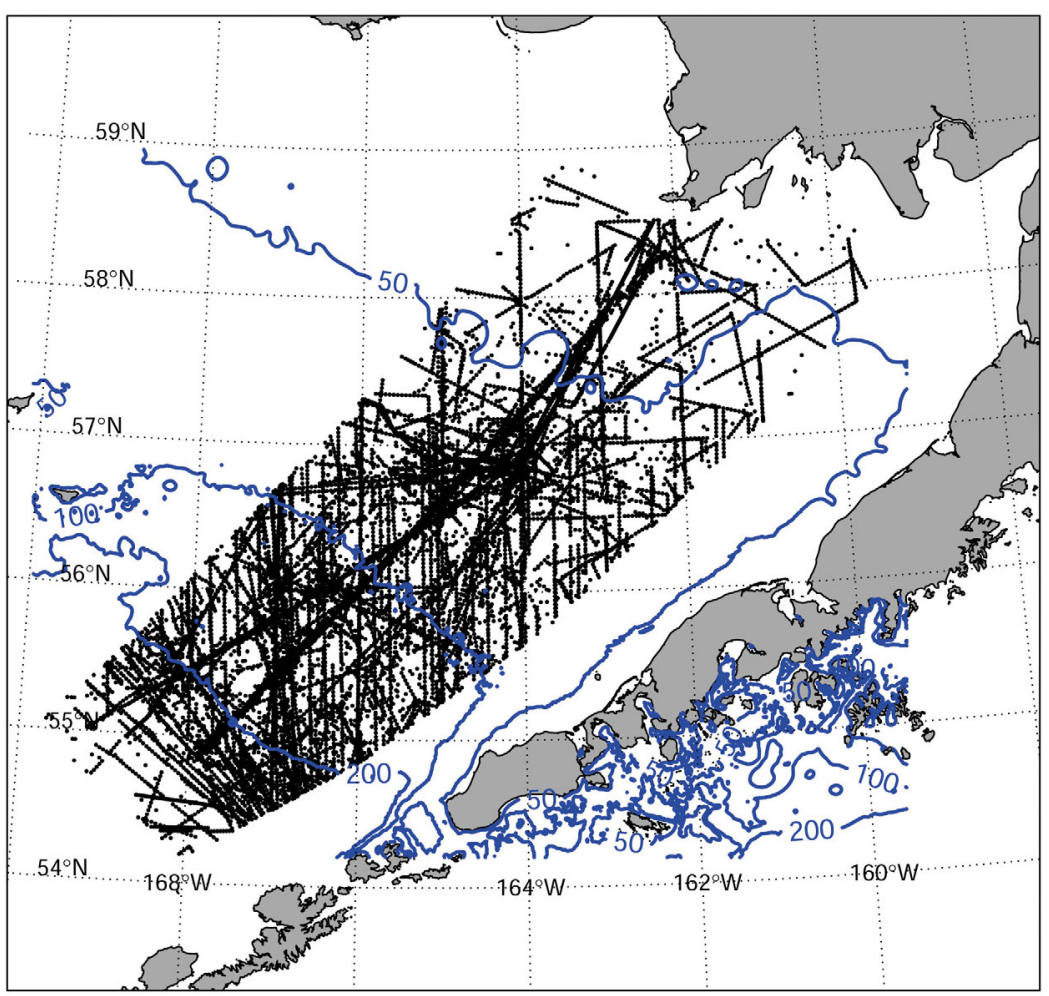

Fig. 1. Study area on the southeastern Bering Sea shelf showing location of survey effort from 1975 to 2014 (small black dots show location of each $1 \mathrm{~km}^{2}$ transect). The 50,100, and $200 \mathrm{~m}$ isobaths are delineated in blue surface expressions (the Inner Front and the Shelf-break Front, see 'Study area and hydrology' below), we expected use of frontal areas by seabirds to be greatest in years with early sea-ice retreat. We did not anticipate a shift toward the Middle Front, because its surface expression is weak (Coachman 1986), and Schneider et al. (1987) had found that if seabirds aggregated at fronts, it was the fronts with a strong surface expression that were attended. Alternatively, if age-0 pollock were most abundant in the Middle Shelf Domain in years with early sea-ice retreat, it could be expected that seabirds that depend on them might increase their foraging in this region.

\section{BACKGROUND AND METHODS}

\section{Study area and hydrology}

Our study area encompassed a portion of the southeastern Bering Sea shelf from a depth of about $20 \mathrm{~m}$ to the shelf edge and beyond over the shelf slope to waters of $2500 \mathrm{~m}$ depth, closely following the area used by Schneider et al. (1986), Hunt et al. (2014), and Renner et al. (2016) (Fig. 1). The north-

west and southeast sides of our study area were selected to minimize the impact of nesting seabirds foraging out from the major colonies of the Pribilof Islands (Jahncke et al. 2008), and to avoid proximity to the Alaska Peninsula and its shallow coastal waters. We assumed that the ecosystem within our study area is largely homogeneous along isobaths, and that the main ecological gradient is depth or is depth-related (Hunt et al. 2014). We therefore based our analysis on bathymetry and regarded samples along an isobath as replicates.

During summer, the waters of the southeastern Bering Sea shelf are characterized by 4 hydrographic domains, the Inner Shelf Domain (depth 0 to $\sim 50 \mathrm{~m}$ ), the Middle Shelf Domain $(\sim 50$ to $\sim 100 \mathrm{~m})$, and the Outer Shelf Domain ( 100 to $\sim 200 \mathrm{~m})$ (Kinder \& Schumacher 1981, Coachman 1986). Here we also identify a Shelf-slope Domain ( 200 to $\sim 2500 \mathrm{~m})$, where there is an abrupt shift from the very gradual increase in depth from the shore to the shelf edge to a rapid increase in depth toward the deep Aleutian Basin (Kinder \& Coachman 1978, Mizobata et al. 2008). These domains are separated by fronts with the degree of surface expression varying temporally and spatially. In summer, the Inner Front separates 
the well-mixed waters of the Inner Shelf Domain from the waters of the Middle Shelf Domain, which are strongly stratified in summer (Schumacher et al. 1979, Kachel et al. 2002). The Middle Front (Coachman \& Charnell 1979, Coachman 1986) separates the 2-layer Middle Shelf Domain from the more oceanicinfluenced Outer Shelf Domain and is largely coincident with a northwestward flow along the $100 \mathrm{~m}$ isobath (Reed \& Stabeno 1996, Stabeno et al. 2016). The Middle Front has its strongest expression at depth (Coachman \& Charnell 1979). The Shelf-break Front separates the Outer Shelf Domain from the Shelf-slope Domain (Kinder \& Coachman 1978) and its associated flows along the shelf slope (Johnson et al. 2004, Okkonen et al. 2004, Ladd 2014).

For the purposes of this paper, we defined the location of the Inner Front as waters of 45 to $55 \mathrm{~m}$ depth, as this front moves significantly depending on tidal strength and wind mixing (Kachel et al. 2002, Jahncke et al. 2005). We defined the Middle Front as waters between 85 and $105 \mathrm{~m}$ depth, and the Shelf-break Front as between 175 and $250 \mathrm{~m}$ depth. These definitions encompassed the range of depths over which the physical expression of these fronts occurs, and provided sufficiently wide regions to capture an adequate sample of seabird observations in the regions of the fronts.

\section{Seabird prey in the southeastern Bering Sea}

To understand seabird responses to years with early and late sea-ice retreat, we needed to know the species composition of their prey and how these prey might change in distribution or abundance in response to the timing of sea-ice retreat. The diets of seabirds in the southeastern Bering Sea are known primarily from samples obtained from breeding birds at colonies (e.g. Sinclair et al. 2008, Dorresteijn et al. 2012, Renner et al. 2012, Paredes et al. 2014), but in a few cases, samples have been obtained from birds collected while foraging at sea (e.g. Schneider et al. 1986, Hunt et al. 1996, Jones et al. 2014). Although a wide variety of prey were used by the birds, the most important prey types identified were large copepods (Neocalanus spp., Calanus marshallae) for least auklets (for Latin names of seabirds, see Table 1); amphipods (Themisto libellula) for thick-billed murres and black-legged kittiwakes; euphausiids (Thysanoessa raschii and $T$. inermis) for black-legged kittiwakes, thick-billed murres, and short-tailed shearwaters; squid for northern fulmars, black-legged kittiwakes, and thick-billed murres; myctophids for blacklegged and red-legged kittiwakes; and juvenile pollock (age-0 or age-1) for short-tailed shearwaters, common murres, thick-billed murres, and black-legged kittiwakes (references above).

For black-legged kittiwakes, thick-billed murres, and short-tailed shearwaters, there has been sufficient pelagic sampling of foraging birds to detect spatial patterns in prey use. For example, blacklegged kittiwakes and thick-billed murres sampled near the Pribilof Islands and Bogoslof Island had strong interannual and regional differences in prey used, with murres showing strong spatial patterns (Jones et al. 2014). Both kittiwakes and murres took more deep-water pelagic fish species and squid when foraging in the outer shelf-slope and in deep off-shelf waters (Jones et al. 2014). Short-tailed shearwater diets varied regionally and perhaps seasonally, with euphausiids, in particular T. raschii, as the principal prey around the Pribilof Islands and in the Middle Shelf Domain, and sand lance Ammodytes hexapterus as an important prey in the near shore Inner Shelf Domain of Bristol Bay in spring (see Appendix) (Hunt et al. 1996, 2002a). In some summers, these shearwaters also took age-0 pollock at, and just seaward of, the Inner Front (Hunt et al. 2002a). For the most part, there are broad dietary overlaps among seabird species in the southeastern Bering Sea and, without collecting a bird, we rarely had a way of knowing what any individual bird at sea had been eating.

\section{Selected prey types}

The zooplankton communities of the southeastern shelf vary by hydrographic domain. The biomass of large, lipid-rich copepods of the Middle Shelf Domain is dominated by C. marshallae/glacialis (termed C. marshallae for brevity), whereas Neocalanus spp. predominate in the Outer Shelf Domain and over the deeper waters of the Shelfslope Domain and the Aleutian Basin (Cooney \& Coyle 1982, Smith \& Vidal 1986, Napp et al. 2002, Coyle et al. 2008). Similarly, the dominant species of euphausiids differ between the Outer Shelf Domain ( $T$. inermis) and the Middle and Inner Shelf domains (T. raschii) (Smith 1991, Coyle \& Pinchuk 2002b, Coyle et al. 2008, Pinchuk \& Coyle 2008). The outer and middle shelf species of euphausiids and copepods differ in life history characteristics and requirements for successful recruitment. 
In particular, both of the dominant large zooplankton species in the Middle Shelf Domain, T. raschii and $C$. marshallae, require food in early spring if they are to produce strong cohorts (Baier \& Napp 2003, Hunt et al. 2016). Both consume ice algae (Baier \& Napp 2003, Wang et al. 2015, Campbell et al. 2016) and, when the ice retreat is late, there is little or no gap in the availability of ice-associated algae and the spring bloom (Brown \& Arrigo 2013, Hunt et al. 2016). Thus, years with late sea-ice retreat are likely to be favorable for the recruitment of large cohorts of C. marshallae and T. raschii over the Inner and Middle Shelf Domains (Baier \& Napp 2003, Coyle et al. 2008, 2011, Hunt et al. 2008, 2011, Eisner et al. 2014), but see Coyle \& Gibson (2017) for an argument that poor over-winter survival of diapausing copepods is responsible for the low biomass of $C$. marshallae in warm years. The biomass of $C$. marshallae in early sea-ice retreat years was only $5 \%$ of that in years with late sea-ice retreat (Renner et al. 2016). Although they live in generally ice-free waters, the shelf-slope and basin-dwelling copepods, Neocalanus plumbchrus/flemingeri and N. cristatus, also appear to be more abundant in cold years with late ice retreat (Ohashi et al. 2013, Eisner et al. 2014). Renner et al. (2016) showed that Neocalanus spp. biomass in years with early sea-ice retreat was $64 \%$ lower than in years with late sea-ice retreat.

Ressler et al. (2014) used acoustic surveys of the southeastern Bering Sea shelf conducted between 2004 and 2010 to establish that there was a greater abundance of euphausiids over the Outer and Middle Shelf Domains in years with colder water temperatures. Similarly, Bi et al. (2015), Hunt et al. (2016), and Renner et al. (2016) provided evidence that T. raschii is less abundant overall in years with early sea-ice retreat. The overall impact of these changes is a severe decrease in the abundance of large, lipid-rich zooplankton over the middle and possibly the outer shelf in years with early sea-ice retreat.

In contrast to $C$. marshallae and $T$. raschii in the Middle Shelf Domain, production of age-0 pollock, an important prey for seabirds and the most abundant ground fish in the study area, is stronger in years with early sea-ice retreat and surface waters that are warmer $\left(0\right.$ to $4^{\circ} \mathrm{C}$, versus -0.5 to $\left.-2.7^{\circ} \mathrm{C}\right)$ when pollock eggs and larvae are present. Pollock eggs thrive in water that is above $0^{\circ} \mathrm{C}$ (Blood 2002), and the early life survival and growth of pollock in the Bering Sea is higher in warmer years (e.g. Quinn \& Niebauer 1995, Napp et al. 2000, Coyle \& Pinchuk $2002 a, b)$. The result is a large cohort of age- 0 pollock in the spring of 'warm' years. Many of these small age-0 pollock remain in near-surface waters (upper $20 \mathrm{~m}$ ) into late summer/early fall, particularly in years with early sea-ice retreat (Moss et al. 2009, Parker-Stetter et al. 2013, 2015, Eisner et al. 2015), and would thereby be more vulnerable to predation by a wider array of seabirds. There is also evidence that in years with early sea-ice retreat and warm surface-layer temperatures, there are more age-0 pollock in the upper mixed layer than in cold years with late sea-ice retreat (Moss et al. 2009, Eisner et al. 2015), which may reflect higher survival of eggs and larvae in warm years.

\section{Years with early vs. late sea-ice retreat}

Several metrics have been used to define warm or cold years, or years with heavy or light sea-ice cover (e.g. Stabeno et al. 2012, Eisner et al. 2014, Hunt et al. 2016, Renner et al. 2016, Sigler et al. 2016). Because mounting evidence supports the hypothesis that the timing of sea-ice retreat is critical for the transfer of primary production to large lipid-rich zooplankton (Coyle et al. 2011, Hunt et al. 2011, 2016, Sigler et al. 2016, but see Coyle \& Gibson 2017 for an alternative view), we elected to base our contrast of years on the timing of sea-ice retreat within our study area, per Renner et al. (2016) (Fig. 1). Within the study area, the southern edge of the sea ice is determined by a combination of wind forcing and melting (Pease 1980, McNutt 1981, Zhang et al. 2010). In spring, depending on wind direction, the ice may either surge southward or retreat northward, only to return a few days later (Sullivan et al. 2014). Thus, there is no clearly defined date of ice retreat. Therefore, to characterize the timing of ice retreat, we used the proportion of ice cover within the study area, between the 50 and $500 \mathrm{~m}$ isobaths, during the month of April. Using this metric, a low proportion of ice cover in April would equate to a year with early sea-ice retreat. Conversely, a high proportion of sea-ice cover in April would equate to a year with late sea-ice retreat. Although years with late sea-ice retreat are usually characterized by cool upper water column temperatures, this relationship does not always hold (for example, a late sea-ice retreat was followed by exceedingly warm sea surface temperatures in late spring and early summer of 1997) (Napp \& Hunt 2001).

We used 2 sources of sea-ice data to determine sea-ice concentrations within the study area. For the period 1972-1994, we obtained weekly sea-ice concentrations, on a $0.25^{\circ} \times 0.25^{\circ}$ grid, from the Joint US-Russian Sea Ice Atlas (Environmental Working 
Group 2000). Overlapping that dataset, from 1978 to the present, we used the National Snow and Ice Data Center Bootstrap algorithm on a $25 \mathrm{~km}$ grid (Comiso 2017). The ice data were reported semi-daily before 1987, and daily since then. Using these data sources, we calculated the daily mean sea-ice concentration in the study area from the ice concentration data points within it. For data before 1987, we used a linear extrapolation of semi-daily or weekly data to provide an estimate of daily sea-ice cover within the study area. Years were then grouped into those with early and late sea-ice retreat, with $80 \%$ of sampled years in the early and late categories (16 yr each) and $20 \%$ as intermediate (Fig. 2).

We found autocorrelation in the timing of sea-ice retreat between years up to a time lag of 1 to $2 \mathrm{yr}$. We do not consider autocorrelation an issue for our study of the summer distribution of seabirds, because migration, dispersion, and displacement by sea ice will have resulted in a fresh re-distribution each year. Thus, for the seabirds, each year was assumed to be an independent sample.

\section{Copepod and age-0 pollock sampling}

The sampling of potential prey for seabirds was done within the study area and the years of the study, but for different purposes. Therefore, not all seabird

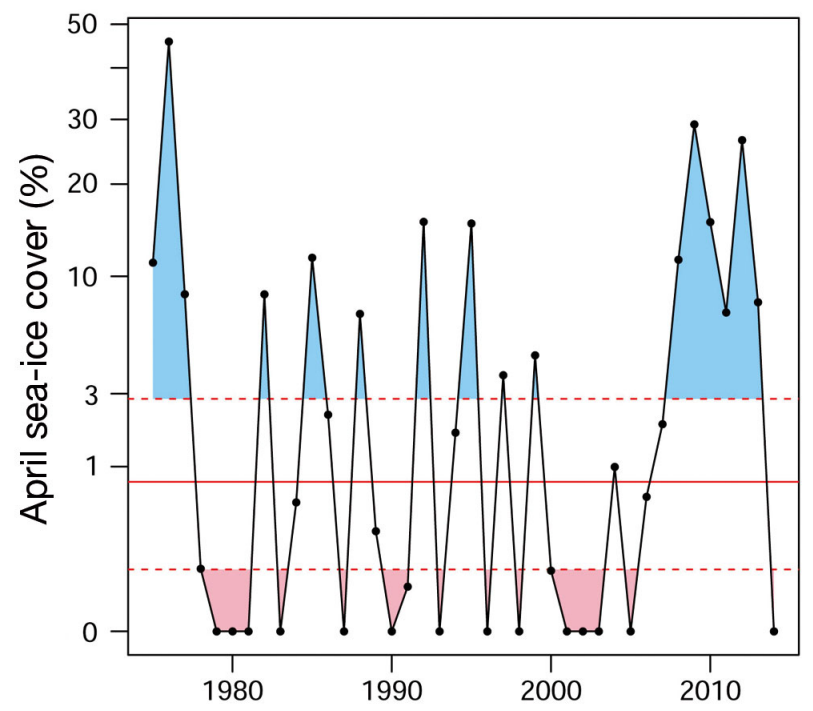

Fig. 2. Classification of years (1975-2014, black dots) as those with early (red) or late (blue) sea-ice retreat based on the $40 \%$ of years with the least ice (early), or $40 \%$ with the most ice (late) present in April. The solid red line is the mean ice cover for April; years between the dashed red lines (40 and $60 \%$ quantiles) were considered intermediate in terms of the timing of sea-ice retreat prey types were sampled, nor were all dates in summer and locations sampled.

Large copepods and age- 0 pollock were sampled during the Bering Arctic Subarctic Integrated Surveys (BASIS) on the southeastern Bering Sea shelf during mid-August to September 2003-2010 (see Fig. 1 in Hunt et al. 2016) following methods in Eisner et al. (2014) and Moss et al. (2009) for zooplankton and fish, respectively. Briefly, large copepods were collected with a $60 \mathrm{~cm}$ bongo frame with $505 \mu \mathrm{m}$ mesh, towed obliquely from near bottom to the surface, and preserved in $5 \%$ formalin buffered with seawater. Samples were sent to the Polish Plankton Sorting and Identification Center (Szczecin, Poland) (2003-2004) or to the University of Alaska (Coyle et al. 2008) (2005-2010), sorted, and counted to estimate abundances (no. $\mathrm{m}^{-2}$ ) of Calanus marshallae and Neocalanus spp.

All stages were combined for C. marshallae and Neocalanus spp. abundance estimates. During August and September, C. marshallae are almost completely comprised of late copepodite stages (C5) in late seaice years (Eisner et al. 2018), but can have higher proportions of earlier stages in years with early sea-ice retreat (A. I. Pinchuk pers. comm.). The size and amount of lipid increase with stage. Therefore, in early-ice years, not only were there fewer C. marshallae, but those that were present may have been less lipid-rich on average (and poorer prey) due a lower percentage of C5 stages. Neocalanus spp. are found in low abundances in August and September compared to earlier months (spring months, in particular) (Eisner et al. 2017). Therefore, these late summer abundances may not accurately reflect their availability over the spring and early summer growing season.

Copepods and age- 0 pollock were sampled over the survey area at 13 to 68 stations $\mathrm{yr}^{-1}$ (mean $\pm \mathrm{SD}=$ $34 \pm 17$ ) from 2003 to 2010 , which included 2 early sea-ice retreat years $(2003,2005), 3$ intermediate years $(2004,2006,2007)$, and 3 late ice retreat years $(2008$, 2009, 2010; Fig. 2). Note that 2004 has been considered a 'warm' year, and 2007 a 'cold' year by others (e.g. Stabeno et al. 2012). In the case of this paper, the difference was the result of sampling more years. Stations were sampled primarily over the Inner, Middle, and Outer Shelf Domains with few offshore stations. Station spacing and area covered varied somewhat from year to year, particularly over the Outer Shelf Domain (e.g. in 2008, no Outer Shelf Domain stations were sampled) (Eisner et al. 2015).

Pelagic fish (e.g. age-0 pollock) were captured with a midwater rope trawl with a mean horizontal spread of $55 \mathrm{~m}$, configured to sample the top 15-35 m of the 

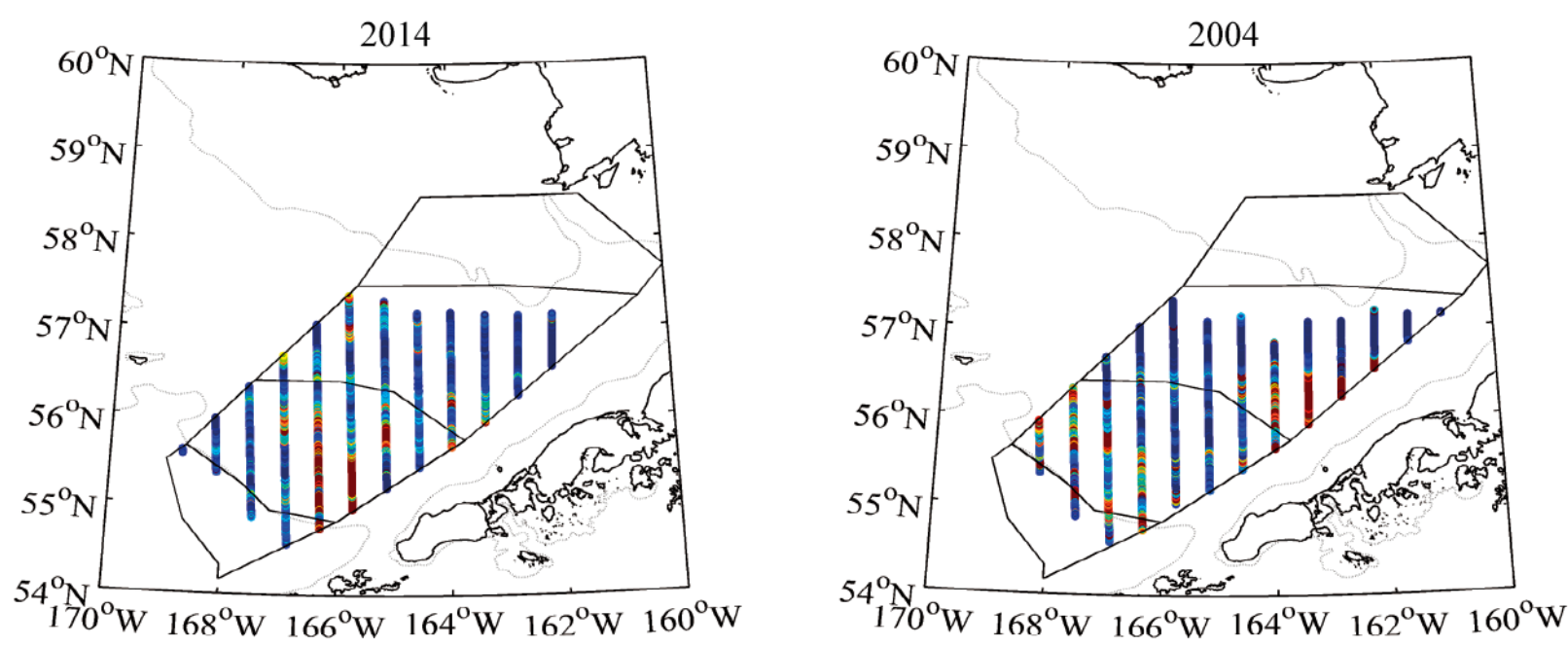

Biomass

$\left(\mathrm{g} \mathrm{m}^{-2}\right)$

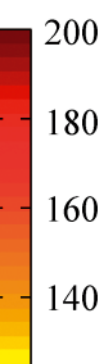

$170^{\circ} \mathrm{W} 168^{\circ} \mathrm{W} 166^{\circ} \mathrm{W} 164^{\circ} \mathrm{W} 162^{\circ} \mathrm{W} 160^{\circ} \mathrm{W}$
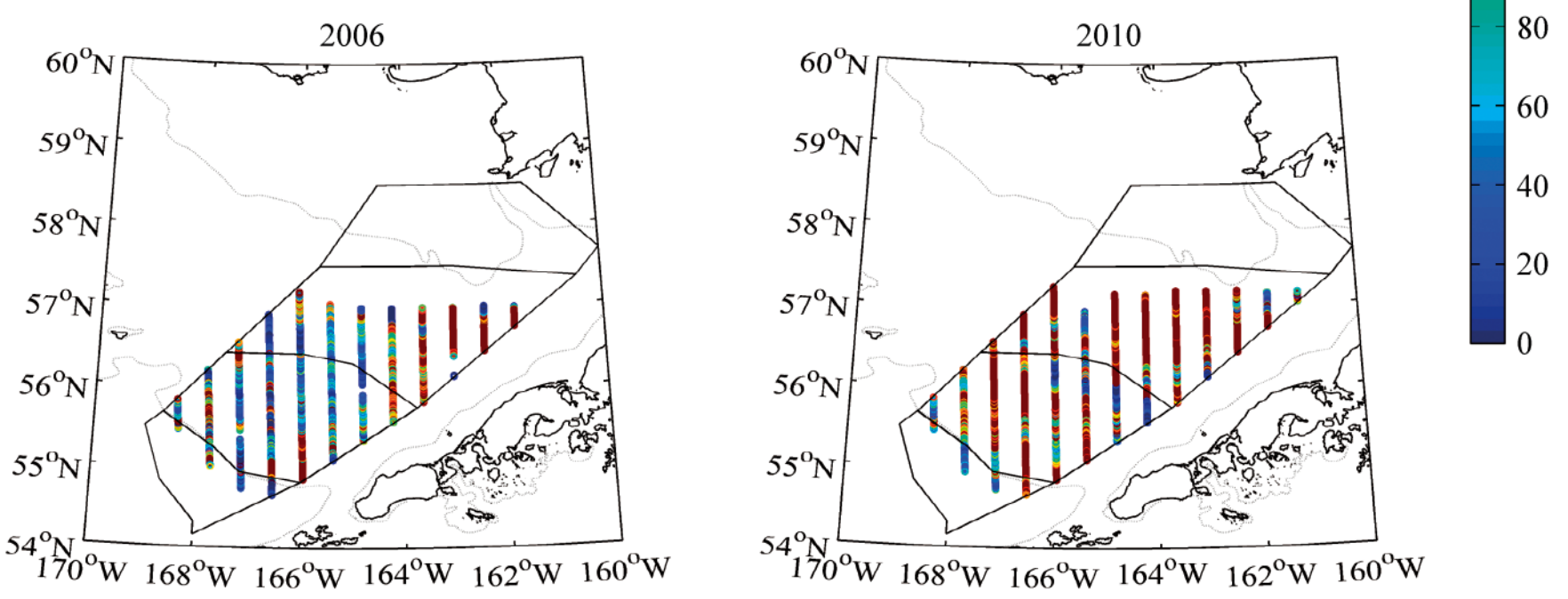

Fig. 3. Acoustic survey effort and euphausiid biomass $\left(\mathrm{g} \mathrm{m}^{-2}\right)$ within Inner, Middle, Outer, and Shelf-slope Domains (black polygons) for years of different sea-ice retreat: 2014 (early), 2004 (neutral), 2006 (neutral), and 2010 (late) (see Fig. 2). 2004 occurred in the middle of a series of warm years with early sea-ice retreat, 2006 was a year of transition from a series of years with mostly early sea-ice retreat to years of later sea-ice retreat, 2010 was in a series of cold years with later sea-ice retreat. 50 and $200 \mathrm{~m}$ isobaths are shown in light gray

water column. The net had a $1.2 \mathrm{~cm}$ mesh cod liner and hexagonal mesh wings. Trawls were towed at 3.5-5.0 knots $\left(6.5-9.3 \mathrm{~km} \mathrm{~h}^{-1}\right)$ for $30 \mathrm{~min}$. The catch was immediately sorted to separate age- 0 pollock from other species and life stages, and pollock were counted to estimate abundances (no. $\mathrm{km}^{-2}$ ). Age- 0 pollock were sampled from the surface layer $(\sim 0-20 \mathrm{~m})$. Therefore, pollock located deeper in the water column were not included. Some seabirds can access prey below the surface layer; this potential food source and its relationship to individual seabird distributions was not evaluated in our study.

\section{Euphausiid sampling}

Ressler et al. (2012) computed the abundance of euphausiids on the middle and outer shelf of the eastern Bering Sea using multi-frequency acoustic backscatter and Methot trawl data from 2004-2014 surveys of midwater pollock (Fig. 3). Methot trawl samples from acoustically detected euphausiid layers were preserved in 5\% formalin:seawater solution and enumerated to determine abundance, size, and species composition at the Polish Plankton Sorting and Identification Center (Szczecin, Poland). 
Estimated euphausiid biomass (wet weight, $\mathrm{g} \mathrm{m}^{-2}$ ) along acoustic survey transects was vertically integrated over the water column and averaged in $0.926 \mathrm{~km}$ (0.5 nautical mile [n mile]) bins along northsouth survey transects (see Hunt et al. 2016, for updated methodology). Euphausiid biomass in crossshelf $25 \mathrm{~m}$ depth bins in years with early and late sea-ice retreat was computed selecting $0.5 \mathrm{n}$ mile acoustic survey intervals and then computing the simple average for a given bin.

Euphausiid survey data were available in 2004, 2006, 2007-2010, 2012, and 2014. The coverage of the study area from approximately 50 to $1000 \mathrm{~m}$ bottom depth was similar in all years (see Fig. 1 in Hunt et al. 2016). Euphausiid data were not available prior to 2004 due to differences in equipment and data collected.

\section{Determination of seabird distributions}

We extracted data from the North Pacific Pelagic Seabird Database (NPPSD; US Geological Survey et al. 2015), excluding aerial surveys contained therein. These data were collected by a variety of researchers conducting visual surveys for marine birds from a wide variety of vessels. For this study, we selected 4855 records from the 'summer' (15 June to 31 August 1975-2014), as the summer should be a period with minimum migratory bird passage through the study area, and the area is ice free (Hunt et al. 2014). We classified seabird species by foraging method, as either surface-seizing or pursuit-diving (Table 1). The sub-set of pelagic data used provided observations over the study area from waters with a depth of about $10 \mathrm{~m}$ to about $2500 \mathrm{~m}$, with the majority having been obtained between about 30 and $2000 \mathrm{~m}$ (Fig. 4). The spatial coverage of the study area was similar in both scenarios, e.g. years with early or years with late sea-ice retreat. The overall number of samples was lower for the years with early sea-ice retreat (Fig. 4).

Records in the NPPSD were developed from counts of seabirds along $300 \mathrm{~m}$ strip transects from directly ahead of a vessel to $90^{\circ}$ off the side with the best visibility. Over time, 2 methods for recording seabird observations have been used. Most recent surveys used the snapshot method (Tasker et al. 1984), thereby addressing the issue of biases from the motion of flying birds relative to the ship. Older surveys in the Bering Sea counted all flying birds, which would lead to an inflated density estimate, if not corrected. We corrected surveys counting all flying birds for flux as described by Renner et al. (2013) and listed in Appen- dix 1 of Hunt et al. (2014). We thus merged density data from the NPPSD from the 2 different methods applied to flying birds. Known biases remain. We made no correction for vessel attraction (although observers attempted to avoid repeated counts of shipfollowing birds), vessel avoidance, or detectability. However, we have no reason to believe that these biases changed across our study area, or were different in years with early or late sea-ice retreat.

\section{Analyses}

The analyses of seabird distribution and abundance followed the approach used by Hunt et al. (2014) and Renner et al. (2016). We first identified outliers in the seabird records and adjusted them, then calculated the abundance (density) of seabirds, by species, in $3 \mathrm{~km}$ segments. The $3 \mathrm{~km}$ segment densities were then averaged within domains to obtain mean density estimates for each depth-defined domain across the shelf (see below). These densities were then used to examine cross-shelf distributions of seabirds in years with early and late sea-ice retreat. For comparison, the average cross-shelf distribution of prey groups was determined by computing a biomass-weighted mean bottom depth for each prey group, and a bootstrap was used to compute a $95 \%$ confidence interval on the difference in mean bottom depth between years with early and late seaice retreat.

\section{Data preparation}

Seabirds identified only to higher taxonomic levels were prorated according to the following: if an unidentified bird could belong to species A, B, or C, we modeled the relative proportion of species $A$ within the sum of identified individuals of species $A$, $\mathrm{B}$, and $\mathrm{C}$ as a smooth function of bathymetry, month, and year using a binomial error distribution with a logistic link-function and no interactions. The level of smoothing was determined through generalized cross-validation (Wood et al. 2008). Prorating was applied sequentially, first to the smallest groups of unidentified species and then to more inclusive groups, as detailed in Appendix 2 of Hunt et al. (2014). We aggregated short-tailed shearwater Ardenna tenuirostris and sooty shearwater $A$. griseus records into 'dark shearwater'. We assumed that the vast majority of shearwaters were short-tailed shearwaters, because that is by far the predominant spe- 
Table 1. Seabird species included in this study, listed by 4-letter code (as used in the figures), their overall density in the study area, their foraging mode (after Ashmole 1971), and their major prey in the southeastern Bering Sea as known, not including offal. For seabird species lacking diet information in the southeastern Bering Sea, we indicate UNDT and provide an indication of diets known from elsewhere, with preferred prey reported by (1) Hunt et al. (1981), (2) Hunt et al. (1996), (3) Hunt et al. (2000), and (4) Schneider et al. (1986). Zoop: zooplankton; krill: euphausiids; deca: decapods; poly: polychaetes

\begin{tabular}{|c|c|c|c|c|c|}
\hline $\begin{array}{l}\text { Abbre- } \\
\text { viation }\end{array}$ & Common name & Latin name & $\begin{array}{c}\text { Density } \\
\text { (ind. } \mathrm{km}^{-2} \text { ) }\end{array}$ & $\begin{array}{l}\text { Foraging } \\
\text { mode }\end{array}$ & Preferred prey \\
\hline ALTE & Aleutian tern & Onychoprion aleuticus & 0.00303 & Surface & UNDT, fish (4) \\
\hline ANMU & Ancient murrelet & Synthliboramphus antiquus & 0.358 & Diver & UNDT, fish, zoop, krill (4) \\
\hline ARTE & Arctic tern & Sterna paradisaea & 0.0582 & Surface & UNDT, fish (4) \\
\hline BFAL & Black-footed albatross & Phoebastria nigripes & 0.00817 & Surface & UNDT, fish, squid (3) \\
\hline BLKI & Black-legged kittiwake & Rissa tridactyla & 0.999 & Surface & Fish, krill, zoop (1) \\
\hline CAAU & Cassin's auklet & Ptychoramphus aleuticus & 0.0255 & Diver & UNDT, zoop (3) \\
\hline COMU & Common murre & Uria aalge & 0.893 & Diver & Fish (1) \\
\hline CRAU & Crested auklet & Aethia cristatella & 0.0143 & Diver & Zoop (1), krill (4) \\
\hline $\mathrm{DCCO}$ & Double-crested cormorant & Phalacrocorax auritus & 0.00000532 & Diver & UNDT, fish (4) \\
\hline FTSP & Fork-tailed storm-petrel & Oceanodroma furcata & 1.68 & Surface & Zoops, squid (3) \\
\hline GLGU & Glaucous gull & Larus hyperboreus & 0.00239 & Surface & UNDT omnivore (4) \\
\hline GWGU & Glaucous-winged gull & Larus glaucescens & 0.0667 & Surface & UNDT omnivore (4) \\
\hline HEGU & Herring gull & Larus argentatus & 0.00111 & Surface & UNDT omnivore (4) \\
\hline HOPU & Horned Puffin & Fratercula corniculata & 0.022 & Diver & Fish, zoop (1) \\
\hline KIMU & Kittlitz's murrelet & Brachyramphus brevirostris & 0.0284 & Diver & UNDT, fish, krill, amphipods (4) \\
\hline LAAL & Laysan albatross & Phoebastria immutabilis & 0.0268 & Surface & UNDT, squid (4) \\
\hline LEAU & Least auklet & Aethia pusilla & 0.0563 & Diver & Zoop (1) \\
\hline LESP & Leach's storm-petrel & Oceanodroma leucorhoa & 0.000356 & Surface & UNDT \\
\hline LTJA & Long-tailed jaeger & Stercorarius longicaudus & 0.00309 & Surface & UNDT \\
\hline MAMU & Marbled murrelet & Brachyramphus marmoratus & 0.18 & Diver & UNDT; fish, amphipods (4) \\
\hline MOPE & Mottled petrel & Pterodroma inexpectata & 0.00286 & Surface & UNDT \\
\hline NOFU & Northern fulmar & Fulmarus glacialis & 5.21 & Surface & Squid, fish (1), (4) \\
\hline PAAU & Parakeet auklet & Aethia psittacula & 0.0631 & Diver & Fish, krill, zoop (1) \\
\hline PAJA & Parasitic jaeger & Stercorarius parasiticus & 0.0101 & Surface & UNDT fish (4) \\
\hline PECO & Pelagic cormorant & Phalacrocorax pelagicus & 0.00188 & Diver & UNDT fish (4) \\
\hline PIGU & Pigeon guillemot & Cepphus columba & 0.000518 & Diver & UNDT fish, deca, poly (4) \\
\hline POJA & Pomarine jaeger & Stercorarius pomarinus & 0.0202 & Surface & UNDT, fish (4) \\
\hline REPH & Red phalarope & Phalaropus fulicarius & 0.243 & Surface & UNDT zoops, krill (4) \\
\hline RFCO & Red-faced cormorant & Phalacrocorax urile & 0.00017 & Diver & Fish, deca (1) \\
\hline RHAU & Rhinoceros auklet & Cerorhinca monocerata & 0.000081 & Diver & UNDT fish (4) \\
\hline RLKI & Red-legged kittiwake & Rissa brevirostris & 0.115 & Surface & Fish (1), krill \\
\hline RNPH & Red-necked phalarope & Phalaropus lobatus & 0.0199 & Surface & UNDT zoop, krill (4) \\
\hline SAGU & Sabine's gull & Xema sabini & 0.00423 & Surface & UNDT \\
\hline STAL & Short-tailed albatross & Phoebastria albatrus & 0.00279 & Surface & UNDT squid, fish (4) \\
\hline TBMU & Thick-billed murre & Uria lomvia & 0.401 & Diver & Fish, krill, poly (1) \\
\hline THGU & Thayer's gull & Larus thayeri & 0.000129 & Surface & UNDT fish, krill (4) \\
\hline TUPU & Tufted puffin & Fratercula cirrhata & 0.326 & Diver & Fish, poly (1) \\
\hline UNSH & Dark shearwaters & Ardenna spp. & 27.6 & Diver (1) & Krill, fish (2), squid (4) \\
\hline
\end{tabular}

cies of shearwater in the region (Howell 2012), and all shearwaters collected at sea were this species (Hunt et al. 1996, 2002a). We excluded loons, grebes, and ducks because they use the area primarily as a migration corridor, but only rarely for foraging, at least in summer.

To avoid having a small number of observations with unusually high densities affect the analyses, we used the following conditions to identify an outlier: (1) >1000 individuals of that particular species had to be observed, and (2) the observation had to be $>10 \mathrm{SD}$ above the mean density for that particular species. Outliers were not removed, but rather their value was set to the maximal value observed within the remaining records of that species. This procedure affected 2 records of black-legged kittiwakes.

\section{Examination of bird data by depth interval}

To examine how the cross-shelf use of the southeastern Bering Sea by seabirds might differ between years with early or late sea-ice retreat, we divided the southeastern shelf into bands of differing bathy- 


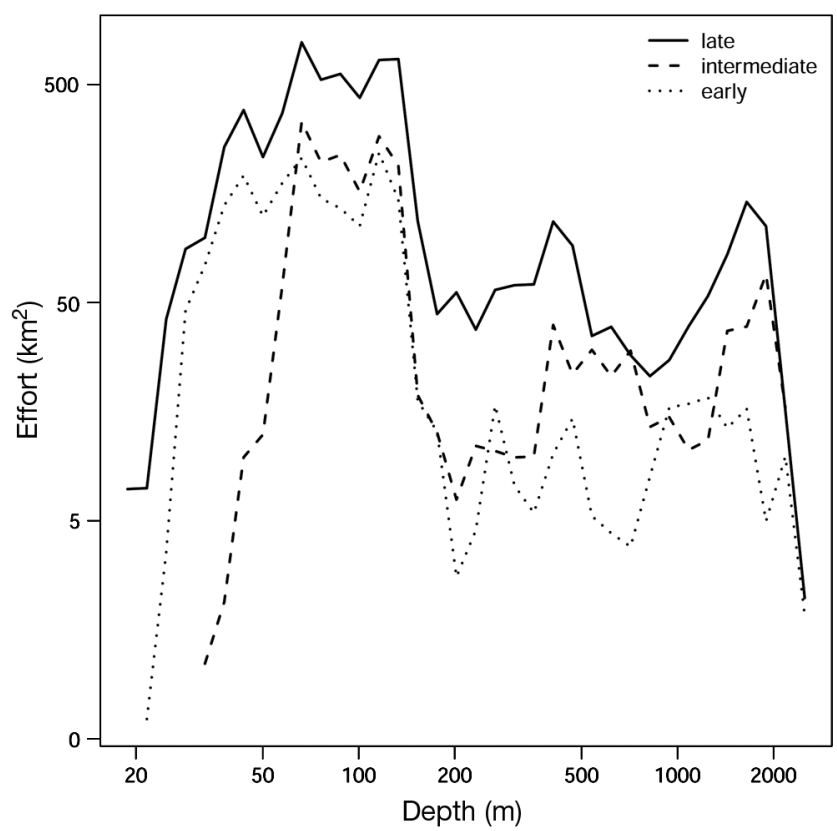

Fig. 4. Seabird survey effort by depth across the study area in years with early, late, or intermediate timing of sea-ice retreat

metry (depth). Bathymetry data were extracted from the Alaska Ocean Observing System (AOOS) bathymetry database (http://portal.aoos.org/\#modulemetadata/8c6e4afa-4294-11e2-920a-00219bfe5678, accessed 30 January 2013). To smooth some of the fine-scale local variation in the $1 \mathrm{~km}$ high-resolution bathymetry which was unlikely to be relevant to seabirds, we applied a $9 \mathrm{~km} \times 9 \mathrm{~km}$ moving average filter.

From northeast to southwest, the ocean floor is gently down-sloping over much of the study area, but then drops rapidly at the continental slope (Fig. 1). We sought a trade-off between sufficient seabird samples within each bathymetry band and spatial resolution. A logarithmic division of bathymetry was chosen rather than linear intervals, because with the inclusion of the shelf break, there were regions (shelf slope) with very rapid changes in bathymetry as compared to the very gradual changes in depth across the shallower portions of the shelf. Therefore, we defined bands to be evenly spaced on a log-scale of depth so that the bounding isobaths would each be 1.15 times deeper than the previous respective isobath (see Fig. 2, top, in Hunt et al. 2014). Because our sampling of seabird distributions was uneven in space and time, the data available were not sufficient to calculate the mean bathymetry-depth distributions of seabird species on an annual basis. To account for variation in the sampling effort among bathymetry bands (Fig. 4), we averaged the density (birds $\mathrm{km}^{-2}$ ) of each species within each band.

\section{Use of frontal areas}

For each seabird species in our study, we calculated the difference of the proportion of that species that was at the Inner, Middle, and Shelf-break Fronts between years with early sea-ice retreat and years with late sea-ice retreat. We used the change in annual proportions rather than an absolute increase or decrease in a frontal region because the total numbers of a species present in the study area often differed significantly between years with early sea-ice retreat and years with late sea-ice retreat (Renner et al. 2016).

\section{RESULTS}

\section{Shifts in the cross-shelf distributions of potential seabird prey}

In years with early sea-ice retreat, the middle and inner shelf copepod Calanus marshallae shifted the center of its distribution toward the deeper waters of the Outer Shelf Domain (Table 2). The shelf-slope copepods Neocalanus spp. and euphausiids appeared to shift their centers of cross-shelf distribution very

Table 2. Shifts in the cross-shelf distributions of selected zooplankton and age-0 walleye pollock within the study area. Confidence intervals (CI) on the difference between the bathymetry centroids (early minus late years) were calculated from 5000 bootstrap replicates

\begin{tabular}{|c|c|c|c|c|}
\hline \multirow[t]{2}{*}{ Prey species/group } & \multicolumn{2}{|c|}{ Depth (m) at location of centroid } & \multirow{2}{*}{$\begin{array}{c}\text { Difference } \\
\text { and } 95 \% \text { CI }\end{array}$} & \multirow[t]{2}{*}{ Years of data } \\
\hline & $\begin{array}{l}\text { Years with early } \\
\text { sea-ice retreat }\end{array}$ & $\begin{array}{l}\text { Years with late } \\
\text { sea-ice retreat }\end{array}$ & & \\
\hline Neocalanus spp. & 142 & 129 & $13(-1,33)$ & $2003-2010$ \\
\hline Euphausiid spp. & 120 & 108 & $12(9,14)$ & $2004,2006,2007-2010,2012,2014$ \\
\hline Calanus marshallae & 130 & 78 & $52(37,65)$ & $2003-2010$ \\
\hline Age-0 Gadus chalcogrammus & 83 & 84 & $-1(-29,19)$ & $2003-2010$ \\
\hline
\end{tabular}


little, with the euphausiids showing about a $10 \%$ depth shift from the inner edge of the Outer Shelf Domain to the middle of that domain in years with early sea-ice retreat (Table 2). Age-0 walleye pollock, which were found chiefly in waters of the Middle Shelf Domain, showed little or no shift in crossshelf distribution (Table 2).

\section{Use of frontal areas by seabirds}

In our test of the hypothesis that seabird species should increase their use of frontal areas in years with early sea-ice retreat, we found no clear pattern of increased use of the Inner, Middle, and Shelf-break Fronts in years with early sea-ice retreat (Figs. 5 \& 6). In years of early sea-ice retreat, 13 of 34 species increased their proportional use of these 3 fronts, whereas 21 decreased their proportional use of these fronts (Figs. 5 \& 7). Among pursuit-diving seabirds, 8 of 15 species decreased their proportional use of the Inner and Shelf-break Fronts in years with early seaice retreat, whereas 7 species increased the proportional use of these fronts. Surface-foraging seabird species showed a lesser use of these fronts in years with early sea-ice retreat: 6 of 19 species increased their proportional use of the Inner, Middle, and Shelf-break Fronts, and 13 species showed a decreased proportional use. Three surface-foraging species (red phalarope, red-necked phalarope, and Laysan albatross) showed increased use of the Middle Front in years with early sea-ice retreat (Fig. 5).

With the exception of the 3 species mentioned above, none of the fronts showed a strong attraction for seabird species in years with early sea-ice retreat, although somewhat more species showed a shift of their centers of distribution to the Inner Front (Fig. 6). In years with early sea-ice retreat, only 3 of the 20 most common species (least auklet, red-necked phalarope, and Arctic tern) had concentrations in the region of the Inner Front (as demarked by steep increases in their cumulative frequency distributions in the region of the front), while glaucous-winged gull, tufted puffin, northern fulmar, and fork-tailed storm-petrel had concentrations in the Shelf-break Front (Fig. 5). In years with late sea-ice retreat, parakeet auklets, least auklets, and Arctic terns had concentrations in the area of the Inner Front, while Arctic terns, fork-tailed storm-petrels, and Laysan albatrosses had concentrations in the Shelf-break Front region (Fig. 5). For none of these species did the elevated numbers within these frontal areas demark the centers of their abundances across the shelf.

\section{Cross-shelf distributions of seabirds}

Despite the lack of increases of seabird densities in frontal areas in years with early sea-ice retreat, there were considerable differences in seabird cross-shelf distributions between years with early and late seaice retreat (Fig. 5). Among the 20 most abundant seabird species in the study area, 7 species shifted their distributions toward deeper water in years with early ice retreat, and 12 species showed shifts toward shallower waters (Fig. 5). In years with early sea-ice retreat, seabird species with mean bathymetry distributions that were shallow tended to move toward deeper waters, whereas those with mean distributions that were at or beyond the shelf edge tended to move toward shallower waters (Fig. 8). When examined by foraging guild, surface-foraging species showed larger shifts in distribution between years with early and late sea-ice retreat than pursuit-diving species, as predicted, but the $95 \%$ confidence intervals overlapped broadly (Fig. 8).

Of the seabird species with the deepest average depth distributions and the strongest shift toward shallower waters in years with early sea-ice retreat, short-tailed albatross (Fig. 8) and Laysan albatross (Figs. $5 \& 8$ ) stand out. These 2 species are surface (or near-surface) foragers, as is the parasitic jaeger (Fig. 8), which also showed a strong shift toward shallower waters. Other offshore surface foragers shifting toward shallower waters in years with early sea-ice retreat included fork-tailed storm-petrel (Figs. 5 \& 8), Leach's storm-petrel (Fig. 8), longtailed jaeger (Fig. 8), and red-legged kittiwake (Figs. 5 \& 8); the latter is a myctophid specialist when breeding. In contrast, black-footed albatross (Fig. 8) tended to shift farther off the shelf, as did the mottled petrel (Fig. 8), a relatively rare species (Table 1). No pursuit-diving species had a strong shift from deep water to the shelf; thickbilled murres (Figs. 5 \& 8) had a center of distribution off the shelf and shifted shelf-ward, but not onto the shelf, in the years with early sea-ice retreat.

In contrast to the 'deep-water' species, seabirds with the centers of their distributions over the middle or inner shelf showed both shifts to deeper water and shifts to shallower waters in years with early sea-ice retreat (Figs. 5 \& 8). Least auklets (planktivores) shifted the center of their distribution inshore from the waters of the Outer and Middle Shelf Domains to offshore of the Inner Front, whereas shearwaters (omnivores) shifted their center of distribution to just inshore of the Inner Front 


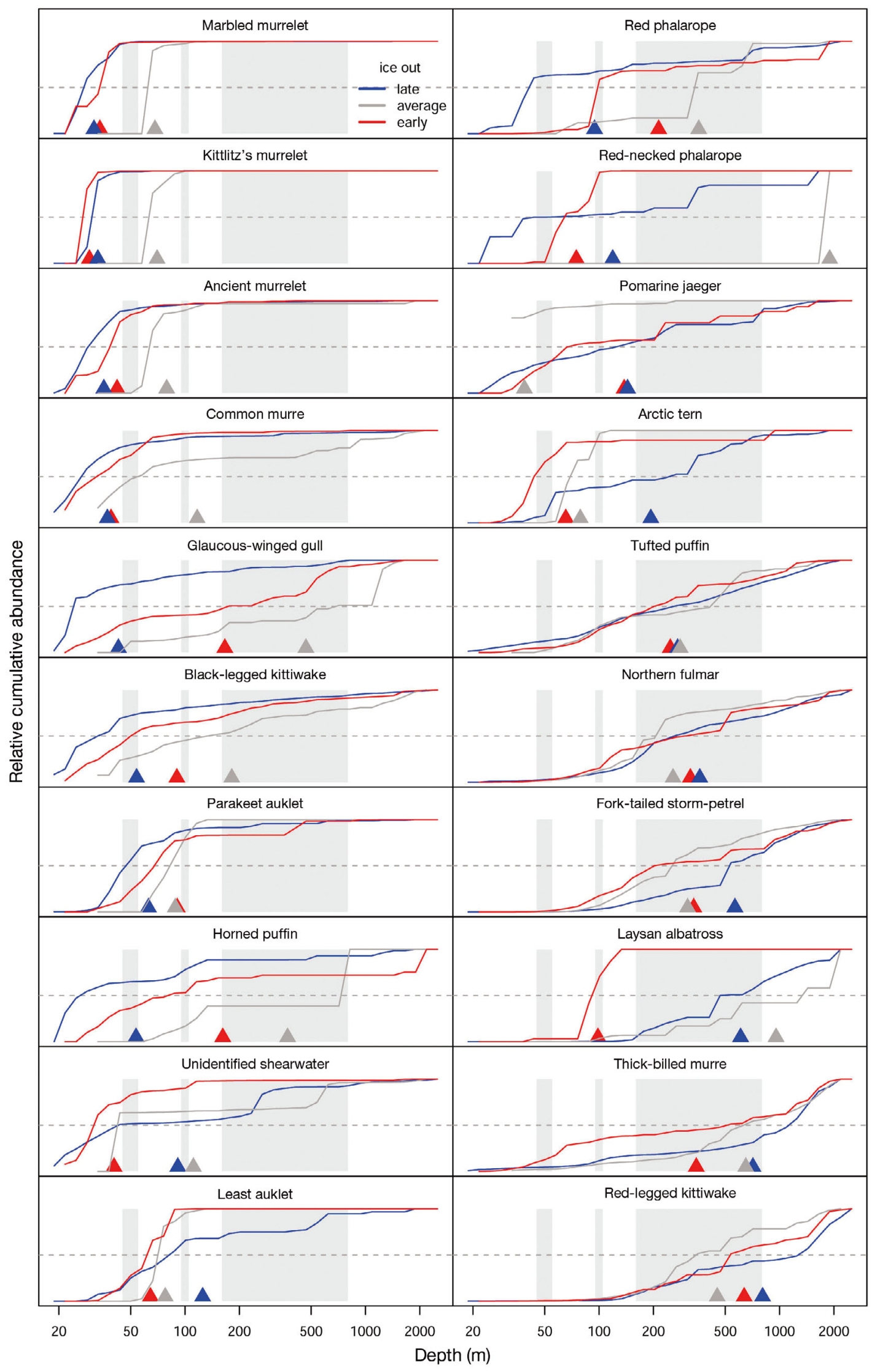


Fig. 5. Cross-shelf cumulative density distributions of the 20 most abundant seabird species in summers of years with early, late, and intermediate timing of spring sea-ice retreat. The Inner Front (45-55 m), the Middle Front (85-105 m), and the Shelfbreak Front (160-800 m) are delineated with grey shading. The grey dotted lines denote $50 \%$ of the cumulative frequency distribution. The triangles are the centers of the distribution of a species in years with early (red), late (blue), and intermediate sea-ice retreat (grey). Panels are arranged as species with predominately shallow-water distributions to those with predominately deep-water distributions

(Appendix, Figs. 5 \& 8). Horned puffins, blacklegged kittiwakes, and glaucous-winged gulls (all piscivores) shifted their distributions offshore from near the Inner Front to near the shelf edge (Figs. 5 \& 8). Others, such as marbled murrelets, Kittlitz's murrelets, ancient murrelets, and common murres, all of which are piscivorous pursuit divers, showed little variation in their depth distributions (Figs. 5 \& 8).

\section{DISCUSSION}

\section{Seabird distributions in years with early and late sea-ice retreat}

It has become increasingly clear that the timing of sea-ice retreat in the southeastern Bering Sea, and/or sea temperatures there, have a profound impact on its marine food webs (e.g. Coyle et al.
2011, Hunt et al. 2011, 2016, Duffy-Anderson et al. 2016, 2017, Farley et al. 2016, Gann et al. 2016, Sigler et al. 2016, Coyle \& Gibson 2017). In our paper, we focused on expanding our understanding of how seabird distributions over the southeastern Bering Sea shelf respond to variations in the timing of sea-ice retreat and the resulting variation in the location and abundance of their prey. Knowledge of how seabirds are dispersed under different climate conditions is a first step in the identification of present areas of importance to seabirds, and how the distribution of these areas may change with climate warming. There may be different sea-ice/ warming pressures influencing offshore and onshore seabirds, as well as different impacts on resident breeders vs. migrants. The stability of regional foraging grounds near seabird colonies will be critical for breeding birds, while migrants may have to keep moving to other seasonal foraging grounds.
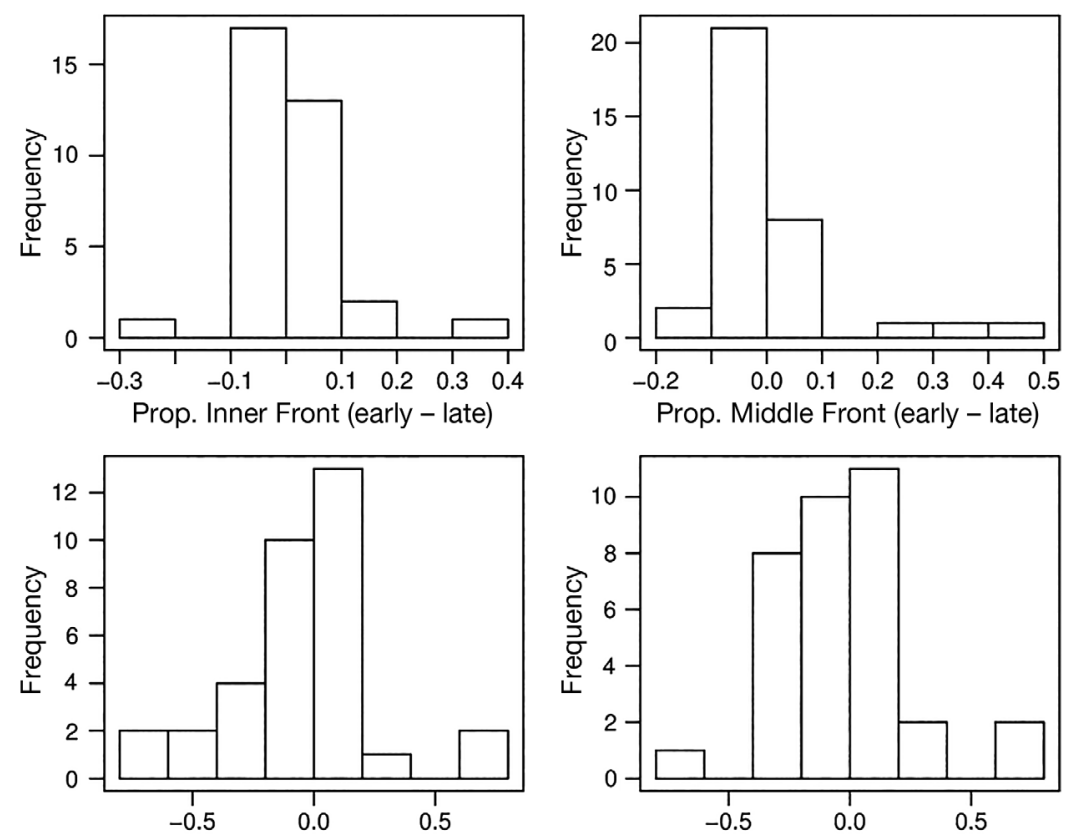

Prop. Shelf-break Front (early - late)

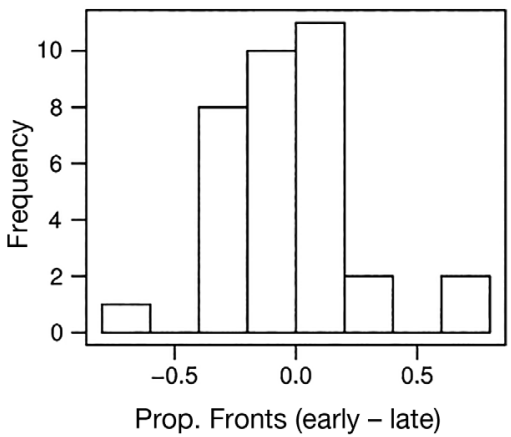

Fig. 6. Frequency distributions of change in the proportion (prop.) of seabirds (all species) using the Inner, Middle, Shelf-break and total Fronts in years with early sea-ice retreat minus years with late sea-ice retreat

\section{Frontal shift hypothesis}

We investigated the hypothesis that seabirds in years of early sea-ice retreat, given a significant reduction in the biomass of both large, lipid-rich copepods (e.g. Calanus marshallae) and euphausiids (Coyle et al. 2011, Hunt et al. 2011, 2016, Renner et al. 2016), would shift their centers of distribution to the Inner Front and the Shelfbreak Front, as these fronts typically are areas of high rates of production in summer (Springer et al. 1996, Kachel et al. 2002, Jahncke et al. 2005). We had also assumed that there would be a seaward shift in the cross-shelf distributions of both C. marshallae and euphausiids, as we expected that their abundances in the Middle Shelf Domain would decline in years with early sea-ice retreat to a greater degree than would occur over the outer shelf (Hunt et al. 2016, Renner et al. 2016, 


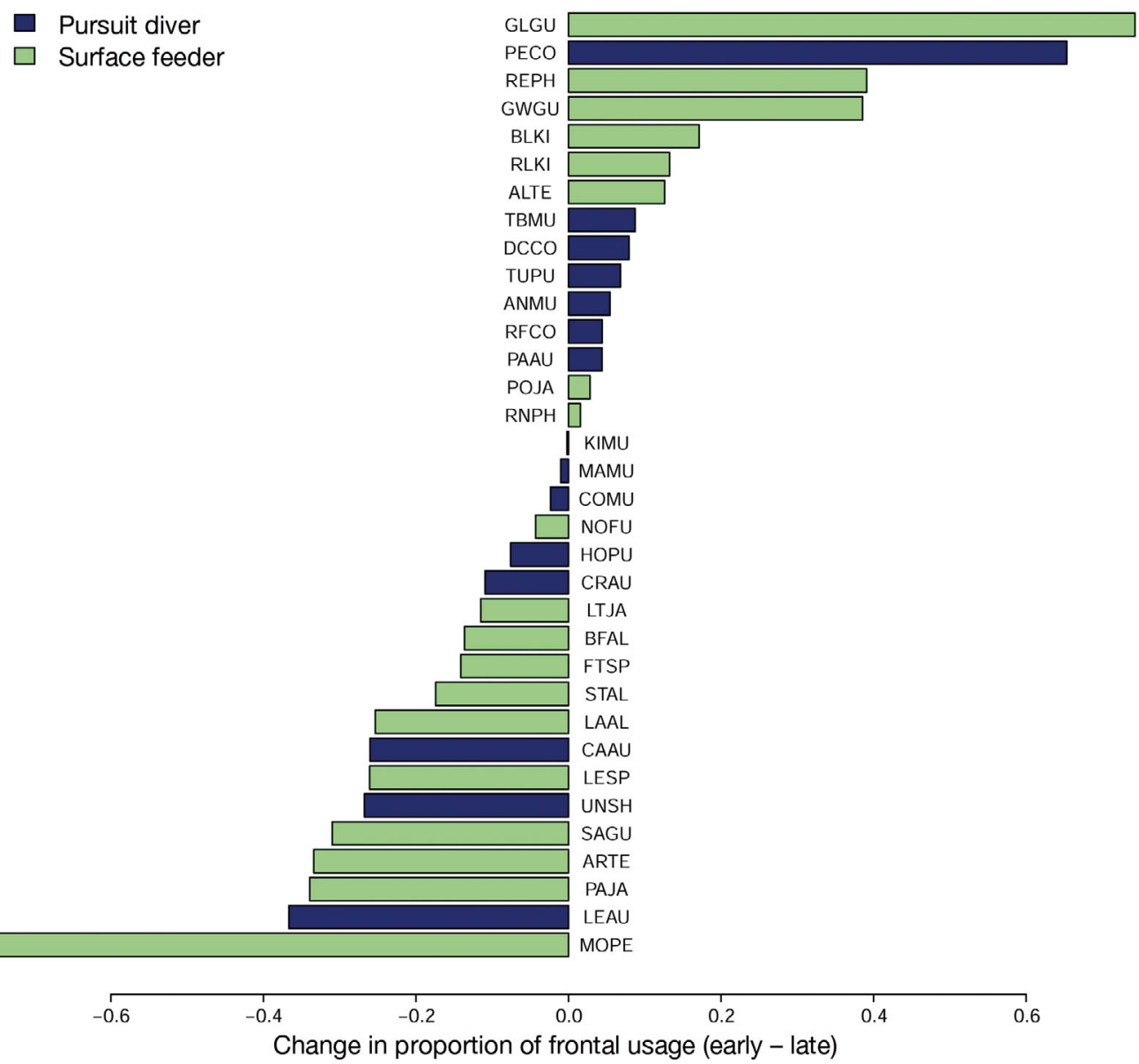

Fig. 7. Change in proportion of a species using of frontal areas (Inner and Shelf-break Fronts, combined), comparing years with late and early sea-ice retreat. See Table 1 for full species names

Sigler et al. 2016). Although, as predicted, we found a significant shift in the center of distribution of $C$. marshallae from the Middle Shelf Domain toward the outer shelf, the cross-shelf shift in the distribution of euphausiids was unexpectedly small. Contrary to our predictions, there was no cross-shelf shift in the centers of distribution of seabirds from the Middle Shelf Domain toward either the Inner Front or the Shelfbreak Front, or to the Outer Shelf Domain. Instead, the most notable cross-shelf shift in seabird distributions was to the Middle Shelf Domain.

In developing our hypothesis of a shift to frontal regions, we had focused on the impacts of the timing of sea-ice retreat on the distribution and abundance of zooplankton and had overlooked the potential impact on the distribution and abundance of age-0 pollock. Earlier work had shown that age-0 pollock were significantly more abundant in surface $(0-20 \mathrm{~m})$ waters of the Middle Shelf Domain in 'warm' years (e.g. Moss et al. 2009). Recent work has shown that age- 0 pollock were about $50 \times$ more abundant in surface waters of the Middle Shelf Domain in years with early sea-ice retreat as compared to years with late sea-ice retreat (Renner et al. 2016), although the proportions of the age- 0 pollock over the middle and outer shelves remained similar, despite the increase in abundance. Blood (2002), Smart et al. (2012), and others have shown that early life stages of pollock fare better in 'warmer' waters, with higher survival and faster growth. Additionally, age-0 pollock preflexion larvae, late larvae, and juveniles are expected to shift inshore onto the shelf in warm years compared to cold years (e.g. a decrease in offshore density of juveniles was observed in warm years), based on modeled results for 1988-2009 (Smart et al. 2012). Most of the seabird species that shifted their centers of distribution into the Middle Shelf Domain are surface foragers that take forage fish as a component of their diet. It is likely that the shift of these seabirds to the middle shelf was motivated by an increased availability of age- 0 pollock there in years with early sea-ice retreat. 


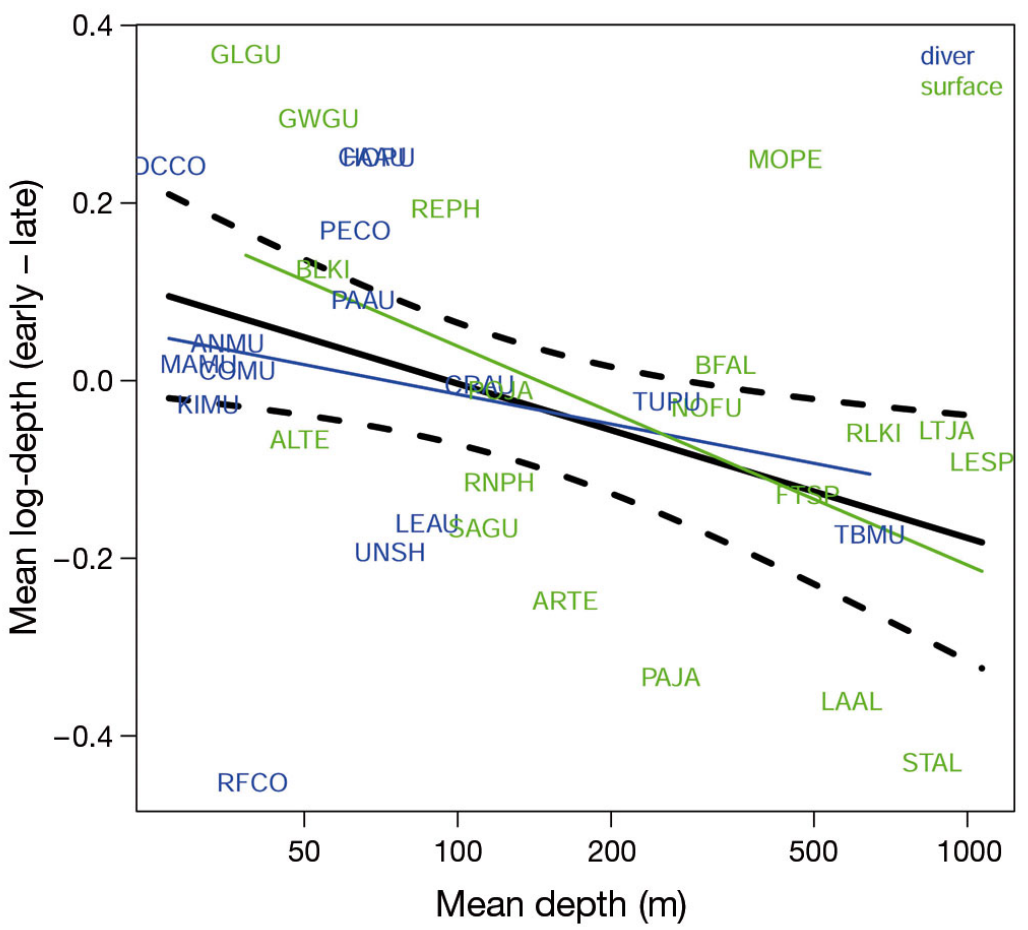

Fig. 8. Extent of change in depth relative to mean depth distribution of seabird species in summers of years with early and with late sea-ice retreat. Species with values below 0.0 mean log depth (early - late) moved shoreward, those above the line moved seaward. The overall effect (black line) is statistically significant at $\mathrm{p}=0.019$. Black dashed lines are $95 \%$ confidence intervals. As expected, surface-foraging species appear to have somewhat greater movements than pursuit diving species, although the difference is not statistically significant $(p=0.26)$. See Table 1 for full species names

billed murre, are surface foragers. The food habits of this group are quite diverse (Table 1), but at least 2 species, i.e. Laysan albatross and the forktailed storm-petrel, are unlikely to have been attracted to upper slope and shelf waters by age- 0 pollock.

An alternative hypothesis is that the deep waters of the outer slope region may become more strongly stratified in warm years than in cool years. Increased heating of the upper mixed layer in warm years could lead to stronger stratification, and an earlier shut down of primary production (see Brown et al. 2011 for a discussion of the impact of warming on primary production over the shelf), but data are lacking to test this hypothesis. If upper mixed-layer productivity dropped, vertically migrating zooplankton and fish might be expected to remain at depth and become less accessible or inaccessible to surface- and near-surface foraging seabirds. In contrast, mixing at the shelf edge (Mizobata et al. 2008), and provision of iron there through the melting of sea ice, could result in a longer, more intense outer shelf bloom in years when sea ice reaches the shelf

Shifts of seabirds from the basin to the outer and middle shelf

Overall, cross-shelf shifts in seabird distributions between years with early and late sea-ice retreat were of the same order of magnitude as the distribution shifts between spring and summer seasons reported by Hunt et al. (2014) (Fig. 9) or between summer and fall as reported by Suryan et al. (2016). One of the most striking patterns was the shift of most seabird species with off-shelf centers of distribution in years with late sea-ice retreat to shallower distributions in years with early sea-ice retreat, which resulted from both a decrease in use of offshelf waters and an increase in the use of shelf waters (See Fig. 1c in Renner et al. 2016). While 3 of the species (red-legged kittiwake, thick-billed murre, and fork-tailed storm-petrel) moved from the outer edge of the 'greenbelt,' a region of high productivity offshore of the shelf (Springer et al. 1996) to the top of the slope, Laysan albatrosses and Arctic terns shifted the center of their distributions well into the Middle Shelf Domain. All of these species, except the thickedge (Aguilar-Islas et al. 2008), consequently resulting in more robust Neocalanus spp. populations. Panteleev et al. (2012) related the Pacific Decadal Oscillation (PDO) signal to eddy kinetic energy in the Bering Sea basin, and Zhang et al. (2010) modeled a strong correlation between the PDO and sea-ice cover over the eastern Bering Sea shelf. It remains unclear how interannual variation in the eddy kinetic energy or sea-ice cover over the shelf may affect variation in seabird prey availability over the basin. This is an area requiring further study.

Little work has been done in slope and near-slope basin waters, but if the productivity of off-shelf surface waters shuts down early in 'warm' years, it could have a strong impact on both fish and seabirds dependent on food resources in the upper mixed layer there. On-shelf shifts in seabird distribution will also likely increase the interactions between the seabirds and the long-line fisheries, with the inevitable result of increased seabird mortality. This increased mortality will be of particular concern in the case of the 3 albatross species that presently, in the eastern Bering Sea, are found mostly near the shelf-slope, as 


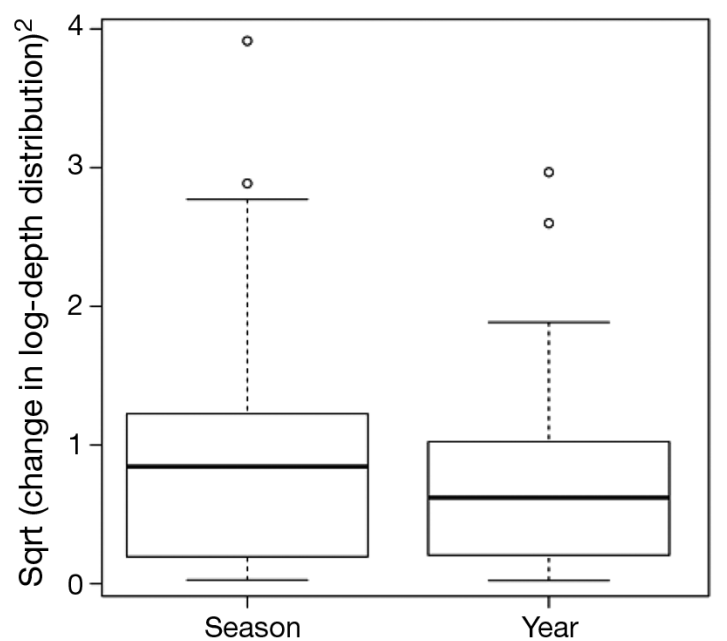

Fig. 9. Comparison of the change in median depth range of seabird species between spring and summer seasons (all years) and between years with early and late sea-ice retreat. Boxes are median with first and third quartiles. Whiskers are 1.5 times interquartile range. Circles are outliers

well as off-shelf, especially given trends toward more frequent 'warm' years.

\section{Inshore shift of shearwaters}

Shearwaters, for the most part short-tailed shearwaters, are the most abundant species of seabird in the southeastern Bering Sea (Hunt et al. 2014, Kuletz $\&$ Labunski 2017). Their distribution pattern changed radically between years with late sea-ice retreat and years with early sea-ice retreat (Renner et al. 2016, this study). Not only did their distribution center shift from the Outer Shelf Domain to just inside the Inner Front, but their numbers were lower in the years of early sea-ice retreat by comparison with years of late sea-ice retreat (Renner et al. 2016). In the years with late sea-ice retreat, shearwaters were spread across much of the shelf, from the shelf-slope region to the Inner Shelf Domain (Renner et al. 2016, this study). However, in the years of early sea-ice retreat, they were concentrated inshore of the Inner Front. Although there are insufficient data to know what attracted shearwaters so far inshore during years with early sea-ice retreat, earlier work has shown that they consume both the shelf euphausiid Thysanoessa raschii and age- 0 pollock in the vicinity of the Inner Front (Hunt et al. 2002a, Baduini et al. 2006). The biomasses of euphausiids and age-1 pollock were significant predictors of shearwater abundance in the southeastern Bering Sea during 2008-2010 (Suryan et al. 2016).

\section{Impacts on seabirds breeding on the Pribilof Islands}

At-sea distributions of prey impact the reproductive ecology and physiology of breeding seabirds. In the southeastern Bering Sea, interannual variability in the availability of both large, lipid-rich zooplankton and age-0 pollock affects the productivity and physiology of seabirds nesting on the Pribilof Islands. Evidence is accumulating that in years with early sea-ice retreat and warm water, black-legged kittiwakes have lower levels of stress hormones, which have been associated with higher reproductive performance, than they do in years characterized by cold water (Satterthwaite et al. 2012, Yamamoto et al. 2016). There is also evidence that some seabird species nesting on the Pribilof Islands shift the region in which they forage between years with early and late sea-ice retreat. For example, Yamamoto et al. (2016) found that pursuit-diving thick-billed murres reduced their foraging in offshelf waters in years with late sea-ice retreat compared to years with early sea-ice retreat, whereas red-legged kittiwakes did not shift foraging areas. Murres also changed their diets between 'warm' and 'cold' water years, with juvenile pollock and sand lance predominating in 2004, a warm year with intermediate sea-ice retreat, and cephalopods, pollock, and sculpins in 2007, a cold year also with intermediate timing of sea-ice retreat (Kokubun et al. 2010). Although the levels of the stress hormone corticosterone did not differ between years in redlegged kittiwakes, in thick-billed murres corticosterone levels were higher in a year with late seaice retreat. Corticosterone levels in planktivorous least auklets nesting on the Pribilof Islands were higher in years with early sea-ice retreat and a reduced proportion of Neocalanus spp. in their diets, suggesting that their preferred prey, i.e. large, lipid-rich copepods, were scarce in these 'warm' years (Dorresteijn et al. 2012).

\section{Implications}

In the short term, occasional periods of warm conditions with early sea-ice retreat may have beneficial effects for seabird species that consume small forage fish such as age-0 pollock. For example, the improved nutritional state of seabirds nesting on St. George Island, such as black-legged kittiwakes and thick-billed murres (e.g. Renner et al. 2012, 2014; Kokubun et al. 2018, this Theme Section), and 
the increases in the pelagic abundances of some seabird species, as reported by Renner et al. (2016), support the hypothesis that the increased abundance of age-0 pollock in surface waters provides a valuable resource for seabirds. On the other hand, most seabird species present in the study area during summer were less abundant during the years of early sea-ice retreat (Renner et al. 2016). Additionally, the advantage of having abundant age-0 pollock in surface waters may be only temporary; during prolonged periods of years with early sea-ice retreat, successive years of small year classes of pollock occur, with a consequent decline in the biomass of pollock (Ianelli et al. 2016). The reduction in the abundance of the large, lipid-rich zooplankton, Calanus marshallae/glacialis and Thysanoessa raschii, over the southeastern Middle Shelf Domain in years with early sea-ice retreat is likely to have a severe impact not only on pollock and cod recruitment (e.g. Farley et al. 2016, Sigler et al. 2016), but also on seabirds and marine mammals dependent directly on these zooplankton, e.g. least auklets nesting on the Pribilof Islands (Dorresteijn et al. 2012). The likely resultant decline in forage fish, not only juvenile pollock, but also capelin and sand lance (Andrews et al. 2016), can be expected to negatively impact piscivorous seabirds and marine mammals in a warming Bering Sea.

The strong shift in the distribution of surfaceforaging seabird species from the deep waters of the basin to the Shelf-slope and Outer Shelf Domains in warm years with early sea-ice retreat was not expected. This shift could reflect either the documented increased availability of age- 0 pollock in surface waters of the middle shelf in early sea-ice retreat years (e.g. Moss et al. 2009, Renner et al. 2016, this paper), or the hypothesized decline in the near-surface availability of prey over deeper waters. The abundance and distribution of squid species may also be influencing seabird distribution in the eastern Bering Sea. Squid distributions and abundances remain largely unknown in the eastern Bering Sea. We require new information on squid as well as on the abundance and near-surface availability of large, lipid-rich zooplankton such as Neocalanus spp., and forage fish, including myctophids, over the deep basin and shelf slope to test these hypotheses. If the shifts in the seabird distributions in years with warm surface waters are indicating a decline in prey resources over the basin, then there are potential long-term implications for the salmon and other large predators that forage in these waters.

\section{CONCLUSIONS}

This study has shown that the cross-shelf distribution of seabirds in the southeastern Bering Sea is related to the timing of sea-ice retreat in spring. Our work supports the hypothesis that these shifts in seabird distributions are likely in response to changes in the distribution, abundance, and availability of their prey. Over the shelf, changes in prey distributions and abundances are related to the reproduction and recruitment of large, lipid-rich copepods and euphausiids and the effects of their availability on the production and vertical distribution of age-0 pollock. Many seabird species shifted the cross-shelf centers of their distributions to the middle shelf region in years with early sea-ice retreat ('warm' years), likely because age- 0 pollock were more abundant in surface $(<20 \mathrm{~m})$ waters than in years with late sea-ice retreat ('cold' years). This result suggests that in future, warmer years, the abundance of these age-0 pollock will be able to support abundant seabird populations. However, other recent studies have shown that the abundances of seabirds in warm years with early sea-ice retreat drop significantly (Renner et al. 2016). Possibly, the declines in large, lipid-rich copepods and shelf euphausiids have a greater negative impact on the seabirds, such as euphausiid-eating shearwaters, foraging over the shelf than the advantages provided by an abundance of lipid-poor age-0 pollock.

We found no general shift of seabirds to the frontal areas during years with early sea-ice retreat, and in fact, concentrations of most seabird species declined in frontal areas under warmer conditions. However, one particularly abundant taxon of seabirds, i.e. dark shearwaters (primarily short-tailed shearwaters), did shift its cross-shelf center of distribution from the outer shelf to inshore of the Inner Front, an area demonstrated to have persistent production throughout summer. This may indicate that the Inner Front is important for sustaining zooplankton and age- 0 pollock populations in years with early sea-ice retreat.

In years with early sea-ice retreat, several seabird species moved the centers of their distributions from the deepest waters that we surveyed to well onto the shelf. This distribution shift may have reflected surface warming (and possible increased stratification) in the deep, offshore waters, as well as higher levels of production over the shelf edge and outer shelf (Brown et al. 2011). It will be important to test these hypotheses, as the implication is that in future warm years, productivity in the upper mixed layer of the 
Bering Sea basin may be reduced, thereby affecting fish populations, such as salmon species, that forage there.

Acknowledgements. We thank the many observers who contributed their pelagic seabird data to the NPPSD and Gary Drew and John Piatt for their foresight and diligent efforts to construct and maintain the NPPSD. Without their efforts, the present paper would not have been possible. We thank Alexis Will, Alexander Kitaysky, and 3 anonymous referees for helpful comments on earlier versions of the manuscript. The North Pacific Research Board (NPRB) provided partial funding for the contributions of G.L.H., M.R., L.E., and J.A.S. via grant NPRB 1408. Seabird surveys conducted by the US Fish and Wildlife Service 2006-2014 were supported by grants to K.J.K. from the NPRB (project nos. 637, B64, B67) and the Bureau of Ocean Energy Management (Interagency Agreement M10PG00050). This is a contribution from the NOAA EMA program, NOAA PMEL contribution 4666, EcoFOCI program paper 0895, and NPRB contribution 562 .

\section{LITERATURE CITED}

Aguilar-Islas AM, Rember RD, Mordy CW, Wu J (2008) Sea ice-derived dissolved iron and its potential influence on the spring algal bloom in the Bering Sea. Geophys Res Lett 35:L24601

Alexander V, Niebauer HJ (1981) Oceanography of the eastern Bering Sea ice-edge zone in Spring. Limnol Oceanogr 26:1111-1125

Andrews AG III, Strasburger WW, Farley EV Jr, Murphy JM, Coyle KO (2016) Effects of warm and cold climate conditions on capelin (Mallotus villosus) and Pacific herring (Clupea pallasii) in the eastern Bering Sea. Deep Sea Res II 134:235-246

Ashmole NP (1971) Seabird ecology and the marine environment. In: Farner DS, King JR (eds) Avian biology, Vol 1. Academic Press, New York, NY, p 223-286

* Baduini CL, Hunt GL Jr, Pinchuk AI, Coyle KO (2006) Patterns in diet reveal foraging site fidelity of short-tailed shearwaters in the southeastern Bering Sea. Mar Ecol Prog Ser 320:279-292

Baier CT, Napp JM (2003) Climate-induced variability in Calanus marshallae populations. J Plankton Res 25: 771-782

Beaugrand G, Kirby RR (2010) Climate, plankton and cod. Glob Change Biol 16:1268-1280

$\mathrm{Bi}$ H, Yu H, Pinchuk A, Harvey HR (2015) Interannual summer variability in euphausiid populations on the eastern Bering Sea shelf during the recent cooling event (20082010). Deep Sea Res I 95:12-19

Blood DM (2002) Low-temperature incubation of walleye pollock (Theragra chalcogramma) eggs from the southeast Bering Sea shelf and Shelikof Strait, Gulf of Alaska. Deep Sea Res II 49:6095-6108

Brown ZW, Arrigo KR (2013) Sea ice impacts on spring bloom dynamics and net primary production in the eastern Bering Sea. J Geophys Res Oceans 118:43-62

Brown ZW, van Dijken GL, Arrigo KR (2011) A reassessment of primary production and environmental change in the Bering Sea. J Geophys Res 116:C08014

Campbell RG, Ashjian CJ, Sherr EB, Sherr BF and others
(2016) Mesozooplankton grazing during spring sea-ice conditions in the eastern Bering Sea. Deep Sea Res II 134:157-172

K Coachman LK (1986) Circulation, water masses, and fluxes on the southeastern Bering Sea shelf. Cont Shelf Res 5: 23-108

* Coachman LK, Charnell RL (1979) On lateral water mass interaction - a case study, Bristol Bay, Alaska. J Phys Oceanogr 9:278-297

* Comiso JC (2017) Bootstrap sea ice concentrations from Nimbus-7 SMMR and DMSP SSM/I-SSMIS, Version 3. NASA National Snow and Ice Data Center Distributed Active Archive Center, Boulder, CO

Cooney RT, Coyle KO (1982) Trophic implications of crossshelf copepod distributions in the southeastern Bering Sea. Mar Biol 70:187-196

* Coyle KO, Gibson GA (2017) Calanus on the Bering Sea shelf: probable cause for declines during warm years. J Plankton Res 39:257-270

Coyle KO, Pinchuk AI (2002a) Climate-related differences in zooplankton density and growth on the inner shelf of the southeastern Bering Sea. Prog Oceanogr 55:177-194

* Coyle KO, Pinchuk AI (2002b) The abundance and distribution of euphausiids and zero-age pollock on the inner shelf of the southeast Bering Sea near the Inner Front in 1997-1999. Deep Sea Res II 49:6009-6030

* Coyle KO, Hunt GL Jr, Decker MB, Weingartner TJ (1992) Murre foraging, epibenthic sound scattering and tidal advection over a shoal near St. George Island, Bering Sea. Mar Ecol Prog Ser 83:1-14

Coyle KO, Pinchuk AI, Eisner L, Napp J (2008) Zooplankton species composition, abundance and biomass on the eastern Bering Sea shelf during summer: the potential role of water column stability and nutrients in structuring the zooplankton community. Deep Sea Res II 55:1775-1791

Coyle KO, Eisner L, Mueter F, Pinchuk AI and others (2011) Climate change in the southeastern Bering Sea: impacts on pollock stocks and implications for the Oscillating Control Hypothesis. Fish Oceanogr 20:139-156

* Dorresteijn I, Kitaysky AS, Barger C, Benowitz-Fredericks ZM, Byrd GV, Shultz M, Young R (2012) Climate affects food availability to planktivorous least auklets Aethia pusilla through physical processes in the southeastern Bering Sea. Mar Ecol Prog Ser 454:207-220

*Dinkwater K (2006) The regime shift of the 1920s and 1930s in the North Atlantic. Prog Oceanogr 68:134-151

* Drinkwater KF, Beaugrand G, Kaeriyama M, Kim S and others (2010) On the processes linking climate to ecosystem change. J Mar Syst 79:374-388

*Duffy-Anderson JT, Barbeaux SJ, Farley E, Heintz R and others (2016) The critical first year of life of walleye pollock (Gadus chalcogrammus) in the eastern Bering sea: implications for recruitment and future research. Deep Sea Res II 134:283-301

\%Duffy-Anderson JT, Stabeno PJ, Siddon EC, Andrews AG and others (2017) Return of warm conditions in the southeastern Bering Sea: phytoplankton - fish. PLOS ONE 12:e0178955

* Eisner L, Yasumiishi E (2016) Large zooplankton abundance as an indicator of pollock recruitment to age-1 and age-3 in the southeastern Bering Sea. In: Zador S (ed) Ecosystem considerations 2014. Stock assessment and fishery evaluation report. North Pacific Fishery Management Council, Anchorage, AK, p 125-128. https://www.afsc. noaa.gov/REFM/Docs/2016/ecosysEBS.pdf 
Eisner LB, Napp JM, Pinchuk A, Andrews A (2014) Climatemediated changes in zooplankton community structure for the eastern Bering Sea. Deep Sea Res II 109:157-171

Eisner L, Siddon E, Strasburger W (2015) Spatial and temporal changes in assemblage structure of zooplankton and pelagic fish across varying climate conditions in the eastern Bering Sea. Izv TINRO 181:141-160

Eisner L, Gann J, Ladd C, Cieciel K, Mordy C (2016) Late summer/early fall phytoplankton biomass (chlorophyll a) in the eastern Bering Sea: spatial and temporal variations and factors affecting chlorophyll a concentrations. Deep Sea Res II 134:100-114

Eisner LB, Pinchuk AI, Kimmel DG, Mier KL, Harpold CE, Siddon EC (2018) Seasonal, interannual, and spatial patterns of community composition over the eastern Bering Sea shelf in cold years. Part I: zooplankton. ICES J Mar Sci 75:72-86

Environmental Working Group (2000) Environmental Working Group Joint US-Russian Arctic Sea Ice Atlas, Version 1. National Snow and Ice Data Center, Boulder, $\mathrm{CO}$

Farley E, Heintz RA, Andrews AG, Hurst TP (2016) Size, diet, and condition of age-0 Pacific cod (Gadus macrocephalus) during warm and cool climate states in the eastern Bering Sea. Deep Sea Res II 134:247-254

Gall AE, Morgan TC, Day RH, Kuletz KJ (2017) Ecological shift from piscivorous to planktivorous seabirds in the Chukchi Sea, 1975-2012. Polar Biol 40:61-78

Gann JC, Eisner EB, Porter S, Watson JT and others (2016) Possible mechanism linking ocean conditions to low body weight and poor recruitment of age-0 walleye pollock (Gadus chalcogrammus) in the southeast Bering Sea during 2007. Deep Sea Res II 134:115-127

Heintz RA, Siddon EC, Farley EV, Napp JM (2013) Correlation between recruitment and fall condition of age-0 pollock (Theragra chalcogramma) from the eastern Bering Sea under varying climate conditions. Deep Sea Res II 94:150-156

*Hermann AJ, Gibson GA, Bond NA, Curchitser EN and others (2013) A multivariate analysis of observed and modeled biophysical variability on the Bering Sea shelf: multidecadal hindcasts (1970-2009) and forecasts (2010-2040). Deep Sea Res II 94:121-139

Howell SNG (2012) Petrels, albatrosses and storm-petrels of North America. Princeton University Press, Princeton, NJ

*Hunt GL Jr, Harrison NM (1990) Foraging habitat and prey taken by least auklets at King Island, Alaska. Mar Ecol Prog Ser 65:141-150

Hunt GL Jr, Schneider DC (1987) Scale dependent processes in the physical and biological environment of marine birds. In: Croxall J (ed) Seabirds: feeding biology and role in marine ecosystems. Cambridge University Press, Cambridge, p 7-41

Hunt GL Jr, Burgeson B, Sanger G (1981) Feeding ecology of seabirds of the eastern Bering Sea. In: Hood DW, Calder JA (eds) The Bering Sea Shelf: oceanography and resources. Office of Marine Pollution Assessment, NOAA. Distributed by the University of Washington Press, Seattle, WA, p 629-647

Hunt GL Jr, Coyle KO, Hoffman S, Decker MB, Flint EN (1996) Foraging ecology of short-tailed shearwaters near the Pribilof Islands, Bering Sea. Mar Ecol Prog Ser 141:1-11

Hunt GL Jr, Russell RW, Coyle KO, Weingartner T (1998) Comparative foraging ecology of planktivorous auklets in relation to ocean physics and prey availability. Mar Ecol Prog Ser 167:241-259
Hunt GL Jr, Mehlum F, Russell RW, Irons D, Decker MB, Becker PH (1999) Physical processes, prey abundance, and the foraging ecology of seabirds. In: Adams NJ, Slotow $\mathrm{R}$ (eds) Proc $22^{\text {nd }}$ Int Ornithol Congr, Durban. BirdLife South Africa, Johannesburg, p 2040-2056

Hunt GL Jr, Kato H, McKinnell SM (eds) (2000) Predation by marine birds and mammals in the subarctic North Pacific Ocean. PICES Scientific Report No. 14, North Pacific Marine Science Organization, Sidney

*Hunt GL Jr, Baduini C, Jahncke J (2002a) Diets of shorttailed shearwaters in the southeastern Bering Sea. Deep Sea Res II 49:6147-6156

Hunt GL Jr, Stabeno P, Walters GE, Sinclair E, Brodeur RD, Napp JM, Bond NA (2002b) Climate change and control of the southeastern Bering Sea pelagic ecosystem. Deep Sea Res II 49:5821-5853

* Hunt GL Jr, Stabeno PJ, Strom S, Napp JM (2008) Patterns of spatial and temporal variation in the marine ecosystem of the southeastern Bering Sea, with special reference to the Pribilof Domain. Deep Sea Res II 55:1919-1944

*Hunt GL Jr, Coyle KO, Eisner LB, Farley EV and others (2011) Climate impacts on eastern Bering Sea foodwebs: a synthesis of new data and an assessment of the Oscillating Control Hypothesis. ICES J Mar Sci 68:1230-1243

*Hunt GL Jr, Renner M, Kuletz KL (2014) Seasonal variation in the cross-shelf distribution of seabirds in the southeastern Bering Sea. Deep Sea Res II 109:266-281

*Hunt GL Jr, Ressler PH, Gibson GA, De Robertis A and others (2016) Euphausiids in the eastern Bering Sea: a synthesis of recent studies of euphausiid production, consumption and population control. Deep Sea Res II 134:204-222

Ianelli JN, Honkalehto T, Barbeaux S, Kotwicki S (2016) Assessment of the walleye pollock stock in the Eastern Bering Sea. In: Stock assessment and fishery evaluation report for the groundfish resources of the Bering Sea/ Aleutian Islands regions. North Pacific Fishery Management Council, Anchorage, AK, p 53-151

Jahncke J, Coyle KO, Zeeman SI, Kachel NB, Hunt GL Jr (2005) Distribution of foraging shearwaters relative to inner front of SE Bering Sea. Mar Ecol Prog Ser 305: 219-233

Jahncke J, Vlietstra LS, Decker MB, Hunt GL Jr (2008) Atsea distributions of marine birds around the Pribilof Islands: a multi-year comparison of temporal and spatial trends. Deep Sea Res II 55:1809-1826

Johnson GC, Stabeno PJ, Riser SC (2004) The Bering Slope Current system revisited. J Phys Oceanogr 34:382-398

* Jones NM, Hoover BA, Heppell SA, Kuletz KJ (2014) A cross-shelf gradient in $\delta^{15} \mathrm{~N}$ stable isotope values of krill and pollock indicates seabird foraging patterns in the Bering Sea. Deep Sea Res II 109:241-250

Kachel NB, Hunt GL Jr, Salo SA, Schumacher JD, Stabeno PJ, Whitledge TE (2002) Characteristics and variability of the inner front of the southeastern Bering Sea. Deep Sea Res II 49:5889-5909

Kinder TH, Coachman LK (1978) The front overlaying the continental slope in the Eastern Bering Sea. J Geophys Res 83:4551-4559

Kinder TH, Schumacher JD (1981) Hydrographic structure over the continental shelf of the southeastern Bering Sea. In: Hood DW, Calder JA (eds) The Bering Sea Shelf: oceanography and resources. Office of Marine Pollution Assessment, NOAA. Distributed by the University of Washington Press, Seattle, WA, p 31-52 
Kokubun N, Iida K, Mukai T (2008) Distribution of murres (Uria spp.) and their prey south of St. George Island in the southeastern Bering Sea during the summers of 2003-2005. Deep Sea Res II 55:1827-1836

Kokubun N, Takahashi A, Ito M, Matsumoto K, Kitaysky AS, Watanuki Y (2010) Annual variation in the foraging behaviour of thick-billed murres in relation to upperocean thermal structure around St. George Island, Bering Sea. Aquat Biol 8:289-298

Kokubun N, Takahashi A, Paredes R, Young RC and others (2018) Inter-annual climate variability affects foraging behaviour and nutritional state of thick-billed murres breeding in the southeastern Bering Sea. Mar Ecol Prog Ser 593:195-208

Kuletz KJ, Labunski EA (2017) Seabird distribution and abundance in the offshore environment, Final Report. US Dept. of the Interior, Bureau of Ocean Energy Management, Alaska OCS Region. OCS Study BOEM 2017-004. Provided to BOEM by the US Fish and Wildlife Service, Anchorage, AK. https://www.boem.gov/2017-004/

Kuletz KJ, Renner M, Labunski EA, Hunt GL Jr (2014) Changes in the distribution and abundance of eastern Bering Sea albatrosses: 1975-2010. Deep Sea Res II 109: 282-292

Ladd C (2014) Seasonal and interannual variability of the Bering Slope Current. Deep Sea Res II 109:5-13

McNutt S (1981) Remote sensing analysis of ice growth and distribution in the Eastern Bering Sea. In: Hood DW, Calder JA (eds) The Bering Sea Shelf: oceanography and resources. Office of Marine Pollution Assessment, NOAA. Distributed by University of Washington Press, Seattle, WA, p 141-165

McRoy CP, Hood DW, Coachman LK, Walsh JJ, Goering JJ (1986) Processes and resources of the Bering Sea shelf (PROBES): the development and accomplishments of the project. Cont Shelf Res 5:5-21

Mizobata K, Saitoh SI, Wang J (2008) Interannual variability of summer biochemical enhancement in relation to mesoscale eddies at the shelf break in the vicinity of the Pribilof Islands, Bering Sea. Deep Sea Res II 55:1717-1728

Moss J, Farley E, Feldmann A, Ianelli J (2009) Spatial distribution, energetic status, and food habits of eastern Bering Sea age-0 walleye pollock. Trans Am Fish Soc 138:497-505

Mueter FJ, Litzow MA (2008) Sea ice retreat alters the biogeography of the Bering Sea continental shelf. Ecol Appl 18:309-320

Mueter FJ, Bond NA, Ianelli JN, Hollowed AB (2011) Expected declines in recruitment of walleye pollock (Theragra chalcogramma) in the eastern Bering Sea under future climate change. ICES J Mar Sci 68:1284-1296

Napp JM, Hunt GL Jr (2001) Anomalous conditions in the southeastern Bering Sea, 1997: linkages among climate, weather, ocean and biology. Fish Oceanogr 10:61-68

Napp JM, Kendall AW, Schumacher JD (2000) A synthesis of biological and physical processes affecting the feeding environment of larval walleye pollock (Theragra chalcogramma) in the eastern Bering Sea. Fish Oceanogr 9: 147-162

Napp JM, Baier CT, Brodeur RD, Coyle KO, Shiga N, Mier K (2002) Interannual and decadal variability in zooplankton communities of the southeast Bering Sea shelf. Deep Sea Res II 49:5991-6008

Niebauer HJ (1998) Variability in Bering Sea ice cover as affected by a regime shift in the North Pacific in the period 1947-1996. J Geophys Res 103:27717-27737

*Niebauer HJ, Alexander V, Henrichs SM (1990) Physical and biological oceanographic interaction in the spring bloom at the Bering Sea marginal ice edge zone. J Geophys Res 95:22229-22241

Nishizawa B, Matsuno K, Labunski EA, Kuletz KJ, Yamaguchi A, Watanuki Y (2017) Seasonal distribution of short-tailed shearwaters and their prey in the Bering and Chukchi seas. Biogeosciences 14:203-214

* Ockendon N, Baker DJ, Carr JA, White EC and others (2014) Mechanisms underpinning climatic impacts on natural populations: altered species interactions are more important than direct effects. Glob Change Biol 20: 2221-2229

* Ogi H, Kubodera TK, Nakamura K (1980) The pelagic feeding ecology of the short-tailed shearwater Puffinus tenuirostris in the subarctic Pacific region. J Yamashina Inst Ornithol 12:157-182

* Ohashi R, Yamaguchi A, Matsuno K, Saito R and others (2013) Interannual changes in the zooplankton community structure on the southeastern Bering Sea shelf during summers of 1994-2009. Deep Sea Res II 94:44-56

\% Okkonen SR, Schmidt GM, Cokelet ED, Stabeno PJ (2004) Satellite and hydrographic observations of the Bering Sea 'Green Belt'. Deep Sea Res II 51:1033-1051

* Panteleev G, Nechaev D, Yaremchuk M, Kukuchi T, Luchin V (2012) Variability of the Bering Sea circulation in the period 1992-2010. J Oceanogr 68:485-496

* Paredes R, Orben RA, Suryan RM, Irons DB and others (2014) Foraging responses of black-legged kittiwakes to prolonged food-shortages around colonies on the Bering Sea shelf. PLOS ONE 9:e92520

*Parker-Stetter SL, Horne JK, Farley EV, Barbee DH, Andrews AG III, Eisner LB, Nomura JM (2013) Summer distributions of forage fish in the eastern Bering Sea. Deep Sea Res II 94:211-230

Parker-Stetter S, Horne J, Urmy S, Heintz R, Eisner L, Farley E (2015) Vertical distribution of age- 0 walleye pollock during late summer: environment or ontogeny? Mar Coast Fish 7:349-369

* Pease CH (1980) Eastern Bering Sea ice processes. Mon Weather Rev 108:2015-2023

* Pinchuk AI, Coyle KO (2008) Distribution, egg production and growth of euphausiids in the vicinity of the Pribilof Islands, southeastern Bering Sea, August 2004. Deep Sea Res II 55:1792-1800

Quinn TJ, Niebauer HJ (1995) Relation of eastern Bering Sea walleye pollock (Theragra chalcogramma) recruitment to environmental and oceanographic variables. Can Spec Publ Fish Aquat Sci 121:497-507

Reed RK, Stabeno PJ (1996) On the climatological mean circulation over the eastern Bering Sea shelf. Cont Shelf Res 16:1297-1305

* Renner HM, Mueter F, Drummond BA, Warzybok JA, Sinclair EH (2012) Patterns of change in diets of two piscivorous seabird species during 35 years in the Pribilof Islands. Deep Sea Res II 65-70:273-291

* Renner HM, Drummond BA, Benson AM, Paredes R (2014) Reproductive success of kittiwakes and murres in sequential stages of the nesting period: relationships with diet and oceanography. Deep Sea Res II 109: 251-265

* Renner M, Parrish JK, Piatt JF, Kuletz KJ, Edwards AE, Hunt GL Jr (2013) Modeled distribution and abundance of a pelagic seabird reveals trends in relation to fisheries. 
Mar Ecol Prog Ser 484:259-277

Renner M, Salo S, Eisner LB, Ressler PH and others (2016) Timing of ice retreat alters seabird abundances and distributions in the southeast Bering Sea. Biol Lett 12: 20160276

Ressler PH, De Robertis A, Warren JD, Smith JN, Kotwicki S (2012) Developing an acoustic index of euphausiid abundance to understand trophic interactions in the Bering Sea ecosystem. Deep Sea Res II 65-70:184-195

Ressler PH, De Robertis A, Kotwicki S (2014) The spatial distribution of euphausiids and walleye pollock in the eastern Bering Sea does not imply top-down control by predation. Mar Ecol Prog Ser 503:111-122

Satterthwaite WH, Kitaysky AS, Mangel M (2012) Linking climate variability, productivity and stress to demography in a long-lived seabird. Mar Ecol Prog Ser 454: 221-235

Schneider DC, Hunt GL Jr, Harrison NM (1986) Mass and energy transfer to seabirds in the southeastern Bering Sea. Cont Shelf Res 5:241-257

Schneider DC, Harrison N, Hunt GL Jr (1987) Variation in attendance at fronts by marine birds in the Bering Sea. Estuar Coast Shelf Sci 25:135-141

Schumacher JD, Kinder TH, Pashinsky DJ, Charnell RL (1979) A structural front over the continental shelf of the Eastern Bering Sea. J Phys Oceanogr 9:79-87

Sigler M, Napp J, Stabeno P, Heintz R, Lomas M, Hunt GL Jr (2016) Variation in annual production of copepods, euphausiids, and juvenile walleye pollock in the southeastern Bering Sea. Deep Sea Res II 134:223-234

Sinclair EH, Vlietstra LS, Johnson DS, Zeppelin TK and others (2008) Patterns in prey use among fur seals and seabirds in the Pribilof Islands. Deep Sea Res II 55: 1897-1918

Smart TI, Duffy-Anderson JT, Horne JK (2012) Alternating temperature states influence walleye pollock early life stages in the southeastern Bering Sea. Mar Ecol Prog Ser 455:257-267

Smith SL (1991) Growth, development and distribution of the euphausiids Thysanoessa raschi (M. Sars) and Thysanoessa inermis (Krøyer) in the southeastern Bering Sea. Polar Res 10:461-478

Smith SL, Vidal J (1986) Variations in the distribution, abundance, and development of copepods in the southeastern Bering Sea in 1980 and 1981. Cont Shelf Res 5: 215-239

Søreide JE, Leu E, Berge J, Graeve M, Falk-Petersen S (2010) Timing in blooms, algal food quality and Calanus glacialis reproduction and growth in a changing Arctic. Glob Change Biol 16:3154-3163

Springer AM, McRoy CP, Flint MV (1996) The Bering Sea green belt: shelf-edge processes and ecosystem production. Fish Oceanogr 5:205-223

Stabeno PJ, Schumacher JD, Davis RF, Napp JM (1998) Under-ice observations of water column temperature, salinity and spring phytoplankton dynamics: Eastern Bering Sea shelf. J Mar Res 56:239-255
Stabeno PJ, Bond NA, Kachel NB, Salo SA, Schumacher JD (2001) On the temporal variability of the physical environment over the southeastern Bering Sea. Fish Oceanogr 10:81-98

Stabeno PJ, Kachel NB, Moore SE, Napp JM, Sigler M, Yamaguchi A, Zerbini AN (2012) Comparison of warm and cold years on the southeastern Bering Sea shelf and some implications for the ecosystem. Deep-Sea Res II 65-70:31-45

Stabeno PJ, Danielson DG, Kachel DG, Kachel NB, Mordy CW (2016) Currents and transport on the eastern Bering Sea shelf: an integration of over 20 years of data. Deep Sea Res II 134:13-29

Sullivan ME, Kachel NB, Mordy CW (2014) Sea ice and water column structure on the eastern Bering Sea shelf. Deep Sea Res II 109:39-56

* Suryan RM, Kuletz KJ, Parker-Stetter SL, Ressler PH and others (2016) Temporal shifts in seabird populations and spatial coherence with prey in the southeastern Bering Sea. Mar Ecol Prog Ser 549:199-215

Sydeman WJ, Poloczanska ER, Reed TE, Thompson SA (2015) Climate change and marine vertebrates. Science 350:772-777

Takahashi A, Ito M, Suzuki Y, Watanuki Y and others (2015) Migratory movements of rhinoceros auklets in the northwestern Pacific: connecting seasonal productivities. Mar Ecol Prog Ser 525:229-243

Tasker ML, Hope Jones P, Dixon T, Blake BF (1984) Counting seabirds at sea from ships: a review of methods employed and a suggestion for a standardized approach. Auk 101:567-577

US Geological Survey, Drew GS, Piatt JF, Renner M (2015) User's guide to the North Pacific Pelagic Seabird Database 2.0. Open-file report. US Geological Survey, Reston, VA

*Wang SW, Budge SM, Iken K, Gradinger RR, Springer AM, Wooller MJ (2015) Importance of sympagic production to Bering Sea zooplankton as revealed from fatty acid-carbon stable isotope analyses. Mar Ecol Prog Ser 518:31-50

Will AP, Kitaysky AS (2018) Variability in trophic level and habitat use in response to environmental forcing: isotopic niche dynamics of breeding seabirds in the southeastern Bering Sea. Mar Ecol Prog Ser 593:247-260

Will AP, Kitaiskaia EV, Kitaysky AS (2018) Red-legged kittiwake feathers link food availability to environmental changes in the Bering Sea. Mar Ecol Prog Ser 593: 261-274

*Wood SN, Bravington MV, Hedley SL (2008) Soap film smoothing. J R Stat Soc Ser B Stat Methodol 70:931-955

*YYamamoto T, Kokubun N, Kikuchi DM, Sato N and others (2016) Differential responses of seabirds to environmental variability over 2 years in the continental shelf and oceanic habitats of southeastern Bering Sea. Biogeosciences 13:2405-2414

K Zhang J, Woodgate R, Moritz R (2010) Sea ice response to atmospheric and oceanic forcing in the Bering Sea. J Phys Oceanogr 40:1729-1747 
Appendix. Prey taken by short-tailed shearwaters collected in the southeastern Bering Sea. PROBES refers to birds collected during the PROBES study (McRoy et al. 1986) in an area roughly congruent with the study area encompassed in the present study. \% occ.: percent of samples in which prey type occurred; \% wt.: percent of the mass of all samples combined; \%vol.: percent of the volume of all samples combined; \% num.: percent of items of a particular group divided by the number of all items present

\begin{tabular}{|c|c|c|c|c|c|c|c|c|}
\hline Year & Season & Area & $\begin{array}{l}\text { Themisto } \\
\text { libellula }\end{array}$ & $\begin{array}{c}\text { Thysanoessa } \\
\text { raschii }\end{array}$ & $\begin{array}{c}\text { Other } \\
\text { euphausiids }\end{array}$ & Zoeae & Fish & Reference \\
\hline $1970 \mathrm{~s}$ & Unknown & North of Pribilofs & $66.7 \%$ wt. & $\begin{array}{l}99.4 \% \text { occ. } \\
20.5 \% \text { wt. }\end{array}$ & & & $\begin{array}{c}\text { Capelin/pollock } \\
12.6 \% \text { wt. }\end{array}$ & Ogi et al. (1980) \\
\hline 1981 & Spring & PROBES & & $82 \%$ vol. & & & & Schneider et al. (1986) \\
\hline 1982 & Spring & PROBES & & 100 \% vol. & & & & Schneider et al. (1986) \\
\hline 1989 & Summer & Around St. Paul Is. & & $100 \%$ num. & & & $0.00 \%$ vol. & Hunt et al. (1996) \\
\hline 1997 & Spring & Inner Front & & $100 \%$ num. & & & & Hunt et al. (2002a) \\
\hline 1997 & Fall & Inner Front & & $41 \%$ num. & $50 \%$ num. & $\begin{array}{l}\text { Zoeae } 8 \% \\
\text { num. }\end{array}$ & $\begin{array}{l}1 \% \text { vol. } \\
\text { pollock }\end{array}$ & Hunt et al. (2002a) \\
\hline 1998 & Spring & Inner Front & & $99 \%$ num. & & & $\begin{array}{l}20 \% \text { vol. } \\
\text { sandlance }\end{array}$ & Hunt et al. (2002a) \\
\hline 1998 & Fall & Inner Front & & $19 \%$ num. & $10 \%$ num. & $\begin{array}{c}\text { Zoeae } 61 \% \\
\text { num. }\end{array}$ & $\begin{array}{l}77 \% \text { vol. } \\
\text { pollock }\end{array}$ & Hunt et al. (2002a) \\
\hline 1999 & Spring & Inner Front & & $49 \%$ num. & $51 \%$ num. & & $\begin{array}{l}41 \% \text { vol. } \\
\text { pollock }\end{array}$ & Hunt et al. (2002a) \\
\hline 1999 & Fall & Inner Front & & $96 \%$ num. & & & $\begin{array}{l}59 \% \text { vol. } \\
\text { pollock }\end{array}$ & Hunt et al. (2002a) \\
\hline
\end{tabular}

Editorial responsibility: Kyle Elliott, Sainte-Anne-de-Bellevue, Québec, Canada
Submitted: July 7, 2017; Accepted: October 24, 2017

Proofs received from author(s): December 12, 2017 